\title{
Excess cerebral TNF causing glutamate excitotoxicity rationalizes treatment of neurodegenerative diseases and neurogenic pain by anti-TNF agents
}

Ian A. Clark ${ }^{* *}$ and Bryce Vissel ${ }^{2,3}$

\begin{abstract}
The basic mechanism of the major neurodegenerative diseases, including neurogenic pain, needs to be agreed upon before rational treatments can be determined, but this knowledge is still in a state of flux. Most have agreed for decades that these disease states, both infectious and non-infectious, share arguments incriminating excitotoxicity induced by excessive extracellular cerebral glutamate. Excess cerebral levels of tumor necrosis factor (TNF) are also documented in the same group of disease states. However, no agreement exists on overarching mechanism for the harmful effects of excess TNF, nor, indeed how extracellular cerebral glutamate reaches toxic levels in these conditions. Here, we link the two, collecting and arguing the evidence that, across the range of neurodegenerative diseases, excessive TNF harms the central nervous system largely through causing extracellular glutamate to accumulate to levels high enough to inhibit synaptic activity or kill neurons and therefore their associated synapses as well. TNF can be predicted from the broader literature to cause this glutamate accumulation not only by increasing glutamate production by enhancing glutaminase, but in addition simultaneously reducing glutamate clearance by inhibiting reuptake proteins. We also discuss the effects of a TNF receptor biological fusion protein (etanercept) and the indirect anti-TNF agents dithio-thalidomides, nilotinab, and cannabinoids on these neurological conditions. The therapeutic effects of 6-diazo-5-oxo-norleucine, ceptriaxone, and riluzole, agents unrelated to TNF but which either inhibit glutaminase or enhance re-uptake proteins, but do not do both, as would anti-TNF agents, are also discussed in this context. By pointing to excess extracellular glutamate as the target, these arguments greatly strengthen the case, put now for many years, to test appropriately delivered ant-TNF agents to treat neurodegenerative diseases in randomly controlled trials.
\end{abstract}

Keywords: TNF, Glutamate, Astrocyte, Synapse, Glutaminase, Re-entry proteins, Neurodegenerative disease, Neurogenic pain

\footnotetext{
* Correspondence: ian.clark@anu.edu.au

${ }^{1}$ Biomedical Sciences and Biochemistry, Research School of Biology,

Australian National University, Acton, Canberra, Australian Capital Territory

0200, Australia

Full list of author information is available at the end of the article
}

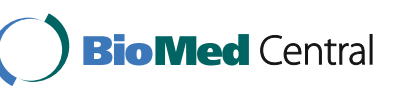

(c) 2016 The Author(s). Open Access This article is distributed under the terms of the Creative Commons Attribution 4.0 International License (http://creativecommons.org/licenses/by/4.0/), which permits unrestricted use, distribution, and reproduction in any medium, provided you give appropriate credit to the original author(s) and the source, provide a link to the Creative Commons license, and indicate if changes were made. The Creative Commons Public Domain Dedication waiver (http://creativecommons.org/publicdomain/zero/1.0/) applies to the data made available in this article, unless otherwise stated. 


\section{Background}

The amyloid theory of Alzheimer's disease, and by extension other chronic neurodegenerative states, has dominated the field for decades. It has, however, in the face of the reality of numerous large clinical trials yielding no clinical improvement, lost momentum. A recent item on the Editor's Blog of the webpage of the Journal of Alzheimer's Disease entitled "Time to Dismount" (see http://www.j-alz.com/editors-blog/posts/time-dismount) eloquently again brings to the fore the long-held, widespread, and increasing unease among researchers [1-5]. Likewise, outcomes comparing in vivo human cerebral amyloid $\beta(\mathrm{A} \beta)$ deposition on Pittsburgh Compound B PET imaging have not generated optimism for the amyloid theory [6, 7]. Recent key epidemiological evidence from a large population in which administering regular subcutaneous etanercept over an extended period in treatment of rheumatoid arthritis (RA) patients was reported to reduce incidence of Alzheimer's disease $(\mathrm{AD})$ [8], further reduces the likelihood of $\mathrm{A} \beta$ being the key to $\mathrm{AD}$ pathogenesis.

We have recently [9] reviewed the literature demonstrating that increased soluble $\mathrm{A} \beta$ does not cause direct damage but is one of the proinflammatory cytokineinduced damage-associated molecular patterns (DAMPs) recognized by toll-like receptors (TLRs). These receptors also recognize pathogen-associated molecular patterns (PAMPs) present on the surface of, for example, the microbes now widely agreed to be sometimes associated with AD [10]. Agonists of TLRs, which are on and in various types of cells, including those throughout the brain, release more of these same cytokines, including tumor necrosis factor (TNF). This is consistent with $\mathrm{A} \beta$ not inhibiting long-term potentiation in hippocampal slices from mice treated with anti-TNF agents, such as infliximab [11]. Clearly, from the literature we have recently quoted [9], A $\beta$ is best regarded, along with S100 proteins and high-mobility group box 1 (HMGB1), as belonging to a class of DAMPs (secondary DAMPs) that exacerbates production of the proinflammatory cytokines responsible for their own increase, and induces them further, causing a forward feed chain reaction. Moreover, variation in levels of these other DAMPs of this same class, possessing the same TLR-mediated, TNF-generating activity in AD, may explain why normal aged patients can exhibit high $\mathrm{A} \beta$ plaque levels. It may also explain why removing soluble $A \beta$ or its plaque, still the goal of the many clinical trials [12], does not retard human disease progression, since the other secondary DAMPs, S100 proteins and HMGB1, are still actively inducing TNF. In contrast, removing $A \beta$ is successful in mouse transgenic models that have been designed to generate pathologically but artificially high $\mathrm{A} \beta$ [13].

Waning enthusiasm for the amyloid theory now allows many other approaches, including the last 10 years of animal studies, case reports, open trials, and off-label treatments of neurodegenerative diseases, based on neutralizing excessive levels of TNF within the brain, to receive more attention. Unaccountably, this neglected approach to neurodegenerative disease is sometimes still referred to as highly controversial [14]. This review provides the logic for increased extracellular cerebral glutamate being the central mechanism by which excessive TNF harms cerebral function and structure. TNF is the first endogenous mediator to be documented as simultaneously influencing extracellular cerebral levels of extracellular glutamate by both enhancing its release and reducing its re-uptake. Given the broad ramifications of glutamate-induced excitotoxicity in infectious and noninfectious disease, these additional layers of information about TNF provide insights with widespread therapeutic implications. In particular, it increasingly rationalizes accounts of the usefulness of neutralizing excess cerebral levels of TNF in neurodegenerative disease.

As well as providing sufficient background to enable the bigger picture of TNF in brain disease pathogenesis to be understood, we focus here on the implications of newer data, largely neglected in the world of neurodegenerative disease, on how this cytokine evidently controls levels of extracellular glutamate in the synaptic cleft. In brief, glutamate is the chief physiological excitatory neurotransmitter, essential of course in memory and learning, and indeed is functionally involved in virtually all activities of the nervous system. Glutamate's combination of functional importance and toxicity demands tight control over its release and re-uptake. Thus, as will be discussed, control by TNF of both of these functions gives treatments based on reducing excess cerebral levels of this cytokine a solid therapeutic foundation in neurodegenerative disease, in part because of its essential effects in driving excitotoxicity. In practice, we may usefully view TNF toxicity and glutamate toxicity as two perspectives on the one pathophysiological entity.

\section{TNF, an extremely pleiotropic cytokine}

TNF was recognized, and named, as an endogenous tumor killing agent [15], and 6 years later, its wider biological importance began to be appreciated through its roles in innate immunity and the pathogenesis of infectious disease ([16], reviewed in 2004 [17]). In due course, fundamental roles for this cytokine in physiological homeostasis [18] and non-infectious disease [19] began to be explored. After being recognized as an early step in the inflammatory cytokine cascade [20], TNF began to achieve its present wide acceptance as a master cytokine in disease pathogenesis through infliximab, the first of the specific neutralizing biological anti-TNF agents, becoming a striking clinical success in treating RA [21]. 
Others from this research group showed that TNF is a master cytokine through observing that infliximab reduces levels of other inflammatory cytokines as well as TNF $[22,23]$.

The extraordinarily broad relevance of TNF in biology can now be inferred by its strongly conserved state, traceable back through a remarkably ancient lineage including fish and insects, with the form generated by reef-building corals, and the TNF receptors on their cells, co-recognizing their human counterparts [24]. Unsurprisingly, therefore, every organ, including the brain, has proved to be influenced by this cytokine. By 1987, TNF had been shown to be a necessary part of the chain of events that control normal sleep [25], and a few years later, current conductance in neurons of a sea slug, Aplysia kurodai, was observed to be reduced by human TNF [26, 27]. Next, physiological levels of TNF had been reasoned to be necessary for normal mammalian neuronal function, with a loss or gain of TNF beyond homeostatic limits being pathological [28]. Nevertheless, data on other proinflammatory or anti-inflammatory cytokines such as IL-1 $\beta$, IL-4, IL-17, and IL-23 [29-31] continue to add to the principles behind this concept and may well generate related therapeutic avenues.

\section{TNF excess in neurodegenerative states}

Twenty years ago, the involvement of unchecked chronic TNF generation, particularly within the brain, in the pathogenesis of stroke, traumatic brain injury (TBI), and AD began to be apparent [32-34]. Refinements of these scientific arguments have accumulated to the present day [35-41]. The subtle relationship between these cytokines and the brain has been nicely put by noting that even when it appears that the nervous system is succumbing to a flared immune system, and the two systems maintain a constant dialogue in the attempt to restore homeostasis [42].

The rationale for treating chronic neurodegenerative states by reducing excess cerebral TNF extends far beyond the post-stroke syndrome, $\mathrm{AD}$, and $\mathrm{TBI}$ noted above. Despite "belonging" to various disciplines, these cerebral states characterized by TNF excess clearly have much pathophysiology in common. They include (Table 1) Parkinson's disease (PD) [43], neurogenic pain [44-50], Huntington's disease [51], amyotropic lateral sclerosis [52], septic encephalopathy [53], defective postoperative cognition $[54,55]$, defective post-irradiation [56] and post-chemotherapy $[57,58]$ cognition, defective cognition during RA [48], epileptic seizures [59, 60], viral encephalitides [61], cerebral malaria [62], and HIV dementia [63]. Moreover, recent evidence has very precisely incriminated excess brain TNF in the pathogenesis of AD [64]. The authors employed a novel multivariate regression modeling approach, termed partial
Table 1 Association of excess TNF and glutamate in brain in neurodegenerative states. See text for references

\begin{tabular}{lll}
\hline Disease & Excess brain & $\begin{array}{l}\text { Excess brain } \\
\text { glutamate }\end{array}$ \\
\hline Alzheimer's disease & + & + \\
Parkinson's disease & + & + \\
Huntington's disease & + & + \\
Amyotropic lateral sclerosis & + & + \\
Septic encephalopathy & + & + \\
Traumatic brain injury & + & + \\
Stroke & + & + \\
Poor post-operative cognition & + & + \\
Poor post-irradiation cognition & + & + \\
Poor post-chemotherapy & + & $?$ \\
cognition & & $?$ \\
Poor cognition in rheumatoid & + & + \\
arthritis & & + \\
Epileptic seizures & + & + \\
HIV dementia & + & + \\
Cerebral malaria & + & + \\
Neurogenic pain & + & + \\
Viral encephalitides & + & + \\
\hline
\end{tabular}

least squares regression, to investigate cytokine protein concentrations in brain tissue from $\mathrm{AD}$ and control patients. Taking into account the order in which brain regions are known to be impacted during the development of $\mathrm{AD}$, region-specific profiles were used to identify high concentrations of cytokines which, when used alone, killed neurons in vitro. Of the 48 cytokines monitored, only TNF (=TNF $\alpha$ in their text) met this condition. This is entirely consistent with the evidence we have previously presented [37] that increased cerebral TNF is the most logical therapeutic target for countering this disease. As we review here, the largely neglected evidence that variation in TNF, through regulating both the release and clearance of cerebral glutamate, seems destined to widen an appreciation of this cytokine within neuroscience as a mediator of plasticity and excitotoxicity.

\section{Glutamate in brain physiology and pathophysiology}

L-glutamate, the most abundant extracellular amino acid in the brain, is, as reviewed over the decades [65-67], the chief physiological excitatory neurotransmitter, including in normal memory and learning. Cerebral glutamate is formed, in microglia and astrocytes [68], as well as neurons, by glutaminase acting on glutamine, and becomes extracellular. Homeostasis is normally maintained by a balance between this reaction and glutamate re-uptake from the synaptic cleft by a series of transport, or re-uptake, proteins that initiate its recycling 
back to glutamine. As discussed below, much literature associates TNF with glutamate regulation. Both too much or too little, TNF and glutamate are harmful. In brief, a plausible paired physiological role for them is low fluctuating levels of TNF determining physiological levels of glutamate in hippocampal homeostatic synaptic plasticity [69, 70], as described below.

As reviewed [66, 71], should extracellular cerebral glutamate become excessive, whether through excess release or poor clearance, or both, a harmful excitotoxicity ensues. From the 1990s, understanding the disruptions that can cause this increase has been an intense focus of interest in the pathophysiology of neurodegenerative diseases. These conditions (Table 1) came to include AD [72], PD [73], Huntington's disease [74], amyotropic lateral sclerosis [75], stroke [76], viral encephelitides [77, 78], septic encephalopathy [79], defective post-operative cognition [80], post-irradiation brain function [81], pain [82, 83], bacterial meningitis [84], epileptic seizures [85], human immunodeficiency virus (HIV) dementia [86], cerebral malaria [87], and TBI [88-90]. In addition, the key studies of Jourdain and co-workers [91] convincingly combined functional and ultrastructural evidence to argue the case for glutamate from astrocytes being a key player in physiological control of synaptic strength. Increasingly, these glutamate pathways have therefore become essential background reading for those whose chief interest has been developing therapeutic drugs for treating these conditions. A recent comprehensive review [92] provides a clear account of the complexities of the control of cerebral extracellular glutamate in chronic, as distinct from acute, excitotoxicity in neurodegenerative states, and discusses amyotrophic lateral sclerosis (ALS), AD, and Huntington's disease as examples. However, this text takes no account of the presence of excess cerebral TNF production or its influence on extracellular brain glutamate levels in these and similar diseases [34, 51, 93-95].

\section{The roles of excess cerebral TNF in generating glutamate toxicity}

\section{Inhibition of re-uptake proteins}

As reviewed in 2001 [96], glutamate re-uptake from the synaptic cleft noted above is controlled by fluctuations in a unique family of amino acid transport, or re-uptake, proteins that act as signal terminators. Their inhibition is intricately involved in the pathogenesis of glutamate-excess excitotoxicity diseases such as stroke, AD, epilepsy, and chronic pain syndromes. Twenty years ago, TNF was first implicated in generating excitotoxicity through its capacity to inhibit glutamate re-uptake in an HIV dementia model [97] and subsequently in cultures brain slices [98] and a Sindbis virus disease model [99]. Although outside the topic of this review, which discusses entry of glutamate into the synaptic cleft rather than its actions while there, we note that emphasis has more recently been placed on the ability of TNF to regulate the various types of glutamate receptors [100]. The details of control of these transport proteins by TNF have more recently been updated in a rat model of ALS [101]. When combined, the ideas generated in these fields of research have allowed insightful functional links of neuroinflammation and glutamateinduced excitotoxicity to be proposed $[102,103]$.

\section{Glutaminase upregulation}

In the event, TNF became much more heavily incriminated in glutamate regulation than has been taken into consideration in the above models of excitotoxocity (Fig. 1). Ten years ago, this cytokine was reported to generate excessive glutamate levels by markedly upregulating glutaminase activity [104]. This was confirmed, as was a concomitant reduction in glutamate re-uptake, in a model of Japanese viral encephalitis [105]. The next year, with the same surprisingly little influence on mainline excitotoxicity research to date, glutaminase upregulation was reported after stimulating primary cultured human neurons with TNF or interleukin-1 $\beta$ [106]. Furthermore, these authors found the glutamate increase to occur in the extracellular space as well as intracellularly. The following year, this group also showed that etanercept reduces inflammation and lethality in the above model of Japanese viral encephalopathy [107]. Clearly, by increasing glutamate production while simultaneously reducing its re-uptake [97], excess TNF can be expected to readily cause glutamate to accumulate to toxic levels. This implies much more therapeutic potential for anti-TNF agents than other drugs possessing only one of these activities, such as 6-diazo-5oxo-norleucine (DON), ceftriaxone, or riluzole, as discussed below. However, this TNF-glutaminase link, despite first being made a decade ago (above), does not yet appear to be common currency in neurodegenerative disease circles (e.g., [108]). Readers interested in the complexities of glutamate release, including its physiological control, are directed to the examples provided by references [109-111].

In passing, we note that glutamine deficiency is a long-recognized characteristic of chronic inflammatory stress and has made nutritionally motivated i.v. glutamine replacement therapy a routine, if formally untested, adjunct treatment in critical care wards [112]. However, a recent post hoc analysis of a large-scale randomized trial has shown this procedure to be of no value, perhaps even harmful [113]. This raises the possibility that chronic TNF increase present in these patients may have caused the observed glutamine depletion by the combined effects of enhancing its conversion to glutamate, plus inhibiting its reconversion from glutamate, as 

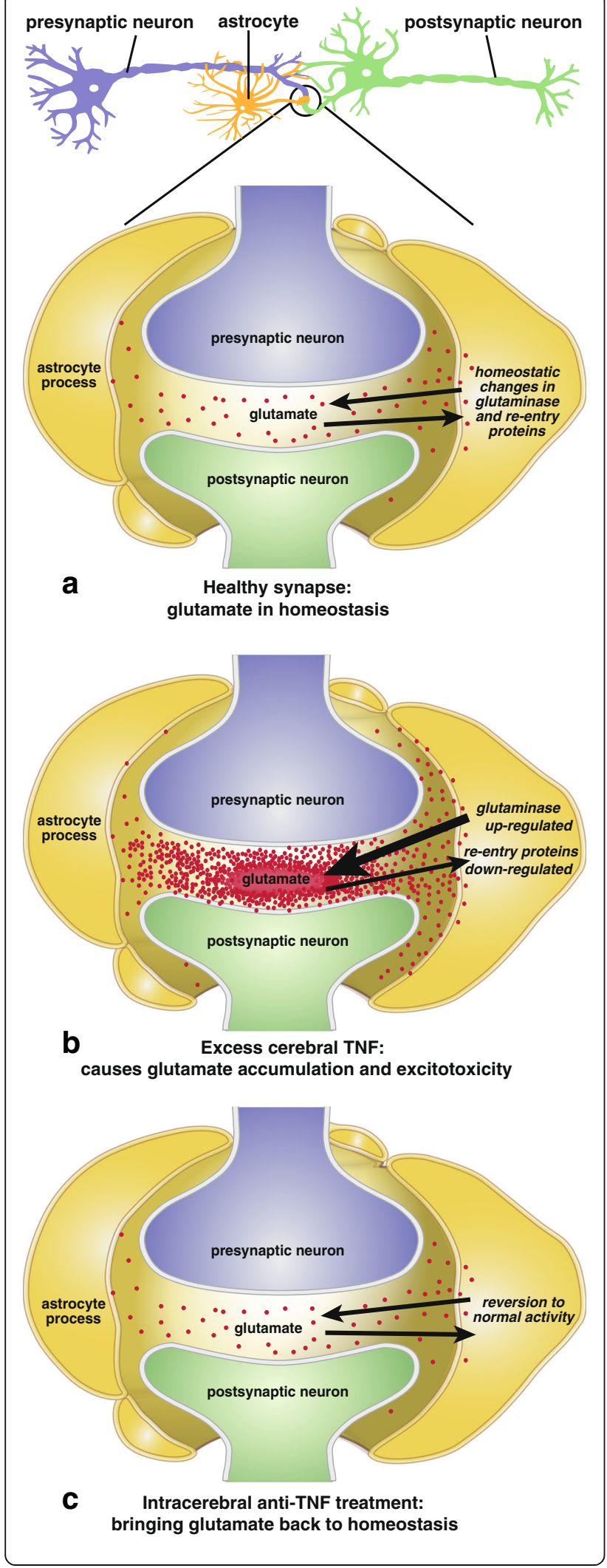

Fig. 1 a Normal synapse, with physiological variations in TNF controlling glutamate levels in synaptic cleft through homeostatic activity of glutaminase and re-entry transporter proteins. $\mathbf{b}$ Excess cerebral TNF enhancing glutaminase and inhibiting re-entry transporter proteins, causing glutamate to accumulate to excitotoxic toxic levels. c Glutamate excess rapidly dispersed from synaptic cleft due to glutaminase reduction plus re-entry protein upregulation. Both occur together after treatment with intracerebral (perispinal) antiTNF biologicals or non-specific TNF inhibitors (dithio-thalidomines, nilotinib, cannabinoids) by other routes. Glutaminase reduction alone occurs with DON, and re-entry protein upregulation alone with ceftriaxone and riluzole

summarized above. Clearly, amino acids have many functions as well as providing nutrients.

\section{Glutamate toxicity as a major manifestation of excess TNF in brain disease}

The above data on TNF provide insights into the breadth of therapeutic relevance of the functional link between unbridled TNF production and glutamate neurotoxicity and how this adds immensely to the central argument of this review that TNF is a highly logical target in neurodegenerate disease. As but one example, the capacity of excess TNF to greatly increase glutamate output through activating glutaminase $[104,105]$ casts the considerable body of work on astrocytes, glutamate, and basal ganglia excitotoxicity, in which the influence of inflammatory cytokines are not considered [114], in a new light. It also modifies the novel "glutamate grabber" approach to treating brain ischemia [115], in that etanercept is, from the above insights, likely to be much more effective than glutamate-oxaloacetate transamimase or oxaloacetate by preventing an excess of newly formed glutamate.

Importantly, intra-amygdala infusion of TNF has been reported to elevate glutamate levels in this region of the brain [116]. Likewise, etanercept, a specific antiTNF biological in wide clinical use, lowers brain glutamate levels in experimental models (Table 2). Although etanercept is too large a molecule for all but a small amount of a subcutaneous (s.c.) dose to enter the cerebrospinal fluid (CSF), intentionally compensating for this by giving a 20 -fold larger dose reduces brain glutamate in a rat model of traumatic brain injury [117]. Etanercept has also been reported, in a heart failure model in which TNF is increased [118, 119], to lower rat brain glutamate dramatically when given intracerebroventricularly (i.c.v), although, again because of its high molecular weight, not when administered intraperitoneally (i.p.). 
Table 2 Outcome of administering specific or non-specific anti-TNF agents in states exhibiting excess cerebral TNF and the opposing effects of TNF and anti-TNF agents of brain glutamate levels. See text for references

\begin{tabular}{|c|c|c|c|c|c|}
\hline & $\begin{array}{l}\text { Excess cerebral TNF } \\
\text { present }\end{array}$ & $\begin{array}{l}\text { Positive outcome after } \\
\text { etanercept, etc. }\end{array}$ & $\begin{array}{l}\text { Positive non-specific TNF inhibitors } \\
\text { outcome }\end{array}$ & & \\
\hline & & & Thalid or dithio-thalid & Nilotinib & Cannabinoids \\
\hline Alzheimer's disease & + & + & + & + & + \\
\hline Parkinson's disease & + & $?$ & $?$ & + & + \\
\hline Huntington's disease & + & $?$ & $?$ & $?$ & $?$ \\
\hline $\begin{array}{l}\text { Amyotropic lateral } \\
\text { sclerosis }\end{array}$ & + & + & $?$ & $?$ & $?$ \\
\hline Septic encephalopathy & + & $?$ & $?$ & $?$ & $?$ \\
\hline Traumatic brain injury & + & + & + & $?$ & + \\
\hline Stroke & + & + & + & $?$ & $?$ \\
\hline $\begin{array}{l}\text { Poor post-operative } \\
\text { cognition }\end{array}$ & + & + & $?$ & $?$ & $?$ \\
\hline $\begin{array}{l}\text { Poor post-chemother } \\
\text { cognition }\end{array}$ & + & $?$ & $?$ & $?$ & $?$ \\
\hline $\begin{array}{l}\text { Poor post-irradiation } \\
\text { cognition }\end{array}$ & + & $?$ & $?$ & $?$ & $?$ \\
\hline Epileptic seizures & + & $?$ & $?$ & $?$ & + \\
\hline HIV dementia & + & $?$ & $?$ & $?$ & + \\
\hline Neurogenic pain & + & + & $?$ & $?$ & + \\
\hline Viral encephalitides & + & $?$ & $?$ & $?$ & + \\
\hline Elevated brain glutamate & + & & & & \\
\hline Lower brain glutamate & & + & $?$ & $?$ & + \\
\hline
\end{tabular}

\section{Do these actions of TNF explain the rapid response to etanercept in neurodegenerative disease?}

Control of glutamate by TNF might also explain why etanercept has often been reported to reverse a number of clinical manifestations of neurodegenerative disease surprisingly rapidly. It was shown 17 years ago [120] that turnover of cerebral extracellular glutamate is very fast, seconds to minutes in these authors' hands. This is evolutionarily essential because of the key role of this amino acid in the synaptic cleft, where it is responsible for the fast excitatory neurotransmission necessary for the rapid brain responses demanded for survival in the real world. Thus, given the role of TNF to influence both glutaminase and reuptake proteins described earlier, the capacity of intracerebral etanercept to lower brain glutamate, as summarized above [117-119], can be expected to act with somewhat the same degree of rapidity. It seems likely, therefore, that these data rationalize the unexpected but clearly rapid response in case reports and open trials to perispinal etanercept, initially reported in 2003 [121] and 2008 [122], and regularly confirmed since [123-127]. Awareness of this 1999 report on the rapidity of extracellular cerebral glutamate turnover [120] may now help contribute to the body of accruing evidence that should alter attitudes regarding reports of rapid responses to anti-TNF in neurodegenerative disease [126, 128].

\section{Therapeutic implications for excitotoxicity in neurodegeneration}

Specific anti-TNF biologicals

Whereas infliximab and adalimumab are essentially monoclonal antibodies directed at TNF itself, etanercept, the only anti-TNF biological drug yet tested in this context, is a fusion protein consisting of the p75 TNF receptor, joined to the constant end of the IgG1 antibody [129]. An etanercept biosimilar is already in the literature $[130,131]$, and a number of others already have approval or are being developed [132], providing the prospect of reduced treatment costs for most of the world. Recent debates on competitive pressures versus scientific rationales delaying introduction of biological biosimilars are most informative [133]. Clearly, regulating this field is a state of flux.

The use of anti-TNF agents in neurodegenerative disease has its critics who largely base their concerns on whether the functional complexities of TNF science, such as the p55 and p75 TNF receptors and membrane versus soluble location of TNF, should be more fully elucidated beforehand [134, 135]. This is largely overplayed: clinical development of the specific anti-TNF biologicals 
in RA, psoriasis, and Crohn's disease went ahead successfully during the past decades alongside continuing yet incomplete basic research without such reservations being aired. The case for cautious use of specific biological anti-TNF agents based on the soundness of the pathophysiological arguments in otherwise untreatable conditions, with an eye to potential concerns, has been amply made in systemic states [136]. In practice, the balance of safety versus outcomes has proved to be very much on the side of the millions of patients who have received regular treatment with these agents for many years now.

\section{Blood-brain barrier (BBB) passage by specific anti- TNF biologicals}

As other therapeutic molecules, the biological anti-TNF agent etanercept, though employed widely with great success systemically, is, as often noted, too large to cross the $\mathrm{BBB}$ in significant amounts unaided. Two BBBcrossing techniques now exist side by side in the literature, the earliest and simplest from a small group, the later technically complex, and not yet tried in patients. Here, we summarize their origins and rationale.

\section{Perispinal delivery of etanercept}

Understanding the perispinal delivery of large molecular weight drugs into the central nervous system requires an appreciation of the cerebrospinal venous system. As recently reviewed in detail [137], this route of cerebral venous drainage has had, since its discovery well over a century and a half ago, a most complex and interesting history, and more recently application, in medical advances. Contemporary awareness of the potential of this route began when researchers in aviation medicine were exploring an animal model of the effects of gravity and body position on pilots of high-performance aircraft [138]. They noted that restraining anesthetized rabbits on a tilt board and rotating them to a head-down position considerably increased CSF levels of the plasma protein albumin within $5 \mathrm{~min}$. The authors noted, in passing, that as well as aiding their branch of science, their data had implications for getting large molecular weight therapeutics into the brain. As discussed $[139,140]$, the principle behind this approach-drug delivery to the brain by retrograde venous flow-began to be used off-label the early 2000s to get etanercept into the brain in patients with neurogenic pain [121] and AD [141]. Although these open trial observations (Table 2) continue to be reported poststroke [125] and TBI [125], and the principles they embrace now have a solid foundation in animal models [50, 55, 142-144], remarkably they have not, as did parallels in inflammatory states in other organs earlier, attracted funding for randomized human trials. As noted above, a wider awareness of the rapid rate of glutamine to glutamate kinetics [120] may well, through rationalizing the reported rapid response [121,122], reduce skepticism.

\section{Trojan Horse delivery of etanercept}

An alternative method of delivery of large molecules into the brain exists [145-147], but it ignores the above input from aviation medicine and, as has been discussed [148-150], remains fraught with technical difficulties. In 2011, the UCLA/Armagen group reported that a re-engineered version of etanercept, in which the IgG part of the fusion protein is a chimeric monoclonal antibody against the mouse transferrin receptor, could be delivered into the mouse brain in this way [151]. The following year, they reported that this reengineered etanercept reduced the harmful effects of experimental stroke in a mouse model [152]. It cannot, however, be tested in humans until etanercept is reengineered so that it recognized human, as distinct from mouse, transferrin. Moreover, re-engineering is essential for each large molecule under consideration, whereas they can be expected to function in their original form when introduced perispinally. A recent review [153] discusses a number of further complexities that need addressing before Trojan Horse delivery could become routinely used.

\section{Non-specific inhibitors of TNF 3,6 Dithio-thalidomides}

Thirty years after being removed from the market in 1961 because of its disastrous effects on fetal development, thalidomide had begun to be explored to treat a number of intractable conditions in patients other than child-bearing age women. It was shown to selectively inhibit TNF production by stimulated human monocytes [154], and to do so by enhancing degradation of the mRNA for this cytokine [155]. A decade later, a series of thio-thalidomides with higher anti-TNF effects than the parent compound were synthesized [156], and the outcomes of their use on TNF mRNA generation closely compared [157]. A considerable literature now exists on some compounds of this class, which are orally active, pass the blood-brain barrier (BBB) and improve outcome in neurodegenerative disease models by inhibiting TNF. They are widely efficacious, by various behavioral and cognitive criteria, in models of lipopolysaccharideinduced neuroinflammation [158], AD [159-161], TBI [55], and stroke [142]. Recently, the parent compound has been reported to reduce a form of neurogenic pain by repressing the inflammatory response [162]. We are unaware of any literature on dithio-thalidomides influencing glutaminase, but the parent compound also has been reported to prevent hypoxia-induced TNF from inhibiting one of the glutamate re-uptake proteins [163]. 


\section{Nilotinib}

Nilotinib, a tyrosine kinase inhibitor, is 30 times more potent than imatinib, which it is replacing for treating certain leukemias $[164,165]$. A small open trial of 6month duration performed at Georgetown University Hospital was reported at the most recent Annual Meeting of the American Society for Neuroscience. Daily oral nilotinib showed promise, in an initial uncontrolled trial, of reversing clinical aspects of PD with or without dementia, as well Lewy Body dementia [166]. Phosphorylated tau (P-tau), $\alpha$-synuclein, and $\mathrm{A} \beta$ were noted to have been significantly reduced [166] in nilotinib-treated patients. Previously, nilotinib had been reported, by this group and others, to be successful in controlled studies in mouse PD models [167-169]. One of these groups [169] demonstrated that a clinically useful proportion of orally administered nilotinib, as used in this new open trial [166], passes through the BBB. Prior animal studies also show that using nilotinib and the closely related dasatinib was useful in models of AD [170-172].

The capacity of nilotinib (and indeed dasatinib [170]) to inhibit TNF generation in vivo $[173,174]$, and the observations that blocking TNF duplicates this effect of nilotinib in PD models [43, 175], appear to have not yet been considered as a plausible mechanism of these new clinical observations with this agent [166]. Nevertheless, as an anti-TNF agent, nilotinab can be expected, from the activity of TNF in these contexts [97, 104], to inhibit glutaminase activity as well as enhance glutaminate reuptake proteins. In addition to nilotinib [176] another selective Src tyrosine kinase, pyrazolopyrimidine-2 (PP2), inhibits production of TNF [177]. Also, given that insulin resistance is a common direct consequence of chronically increased TNF [178], further evidence for anti-TNF effects being central to these observations with nilotinib comes from the ability of these tyrosine kinase inhibitors to treat type 2 diabetes mellitus (T2DM) by decreasing insulin resistance [179].

How might nilotinib reduce TNF levels? Tyrosine phosphorylation is central to TLR stimulation and subsequent activation of NF-kappaB [180] that generates cytokines such as TNF. Endotoxin tolerance is associated with inhibited phosphorylation Src, a non-receptor tyrosine kinase protein [181]. It is therefore plausible that agents such as nilotinib, which inhibit Srcs, reduce TNF production $[173,174]$ by mimicking tolerance to TLR agonists such as endotoxin.

\section{Cannabinoids}

As reviewed [182], the therapeutic and pharmacological secrets of Cannabis sativa have fascinated researchers for about two centuries. About 90 phytocannabinoids (i.e., compounds present in the plant) have been identified, the two with the largest literatures being tetrahydrocannabinol
(THC) and cannabidiol (CBD). The former is psychotropic and thus under a legal cloud, although a synthetic trans-9-delta isomer, termed dronabinol, is an example of forms of THC nowadays undergoing limited investigation [183]. CBD, in contrast, does not cause significant behavioral change and is researched much more widely. These phytocannabinoids, self-evidently BBB permeable, proved to be ligands for two previously unsuspected receptors, mainly found on cells of the immune system, and whose presence led to the prediction and discovery of endogenous cannabinoids, or endocannabinoids. In physiological terms, these may be considered as part neurotransmitter, part cytokine, and part hormone and have been identified and studied at length (see $[184,185]$ for reviews.)

Both endocannabinoids and CBD have been shown to be active in models for pain [186-190], AD [191-195], epileptic seizures [196-199], PD [200-202], HIV dementia [203-205], viral encephalitis [206], and TBI [207]. Clearly, this list parallels the conditions, discussed earlier, with which excessive cerebral levels of TNF are associated. These agents are also active in hypoxic encephalopathy, a stroke parallel in newborns [208, 209], a condition associated with raised inflammatory cytokines and glutamate [210]. Not surprisingly, therefore, cannabinoids, whether synthetic, endogenous, or of plant origin, have proven to be established anti-TNF agents in vitro and in vivo, in the sense that they reduce its production by the usual recognized stimuli [211-214]. This list includes treating the murine malarial encephalopathy (cerebral malaria) [214], a condition in which, as discussed below, 6-diazo-5-oxonorleucine is also efficacious for a related and predictable reason concerned with lowering extracellular cerebral glutamate [215].

Again, the list of model conditions investigated for therapeutic use of cannabinoids in the previous paragraph remarkably mirrors the list of previously discussed conditions associated with excessive cerebral extracellular levels of glutamate. Moreover, treatment with cannabinoids or altering the function of their cellular receptors [185, 191, 216-221] has been reported to lower the levels, or function, of brain glutamate (Table 2). This is entirely consistent with their activity as anti-TNF agents [211-214].

\section{Agents that do not influence TNF but still reduce extracellular brain glutamate \\ 6-Diazo-5-oxo-norleucine (DON), a glutaminase inhibitor}

DON, a glutamine analogue, is studied largely with a view to reduce extracellular glutamate, and thus treat glutamate toxicity, through inhibiting glutaminase. Having been earlier shown [222] to possess anti-tumor properties, nearly 40 years later, DON was reported to inhibit glutaminase and thus reduce the release of glutamate in the rat cerebral cortex [223]. Through the last decade, 
DON has been a useful, albeit often toxic [224], experimental tool to demonstrate that glutamate-mediated excitotoxicity is a significant component of the pathogenesis of various neurodegenerative states, including brain ischemia [225]. Cerebral glutamate homeostasis is disrupted in mouse models of both the neurological sequelae of Sindbis virus infection [226] and malarial encephalopathy caused by Plasmodium berghei ANKA [87], and DON has been successfully used therapeutically in experimental versions of both conditions [215, 227]. It has also been useful in an in vitro HIV dementia model [228] and in both in vitro and ex vivo experimental autoimmune encephalitis, a mouse model of multiple sclerosis [229].

These new data on DON and the relationship between TNF and glutamate excess through glutaminase enhancement put historic observations on malarial encephalopathy into clearer focus. As has been reviewed [17], malaria was the first disease, infectious or otherwise, for which TNF was argued to be central to its pathogenesis, and it set the pattern for the rest. Yet a large trial of a specific anti-TNF antibody, injected intravenously, failed to show evidence, in a large trial in West Africa, of any protective effect in children with cerebral malaria [230]. At that time, however, ideas on malarial disease were predicated on harmful levels of TNF being produced intravascularly, where the parasites that stimulate its production reside, so it was considered logical to administer the antibody into this compartment. Not until 8 years ago was the excess TNF in cerebral malaria shown to originate in the brain [62]. These authors predicted that interventions to decrease TNF production in the brain might be required in order to improve outcomes. Thus, treating human cerebral malaria with perispinal etanercept, evidently an equivalent to administering it i.c.v. [125], will have at least as good and theoretically better ability-since it would also enhance re-uptake proteins-as DON to reduce excessive levels of glutamate, and therefore improving clinical outcome. DON, a molecule not known to affect re-uptake proteins, but which inhibits glutaminase [223], as well as passes the BBB when given i.p. [231], has recently also been effective in treating mice infected with Sindbis virus [227] as well as the cerebral malaria model discussed above [215].

\section{Ceftriaxone and riluzole, glutamate re-uptake transporter enhancers}

Ceftriaxone is a broad-spectrum beta-lactam antibiotic, largely reserved, in this context, for use against otherwise resistant bacteria. In contrast to cannabinoids and nilotinib, it has been shown not to reduce TNF release from LPS-treated human monocytes [232], implying it does not act against excitotoxicity by inhibiting TNFmediated glutaminase enhancement [97] or enhancing TNF-mediated reduced glutamate re-uptake [104]. In
2007, ceftriaxone was shown to independently enhance glutamate re-uptake and thus reduce the glutamatedependent portion of morphine-dependent hyperthermia [233]. This activity of ceftriaxone was soon shown, in primary fetal human astrocytes, to operate through increased expression of excitatory amino acid transporter 2 (EAAT2) promoter activity, allowing it to inhibit glutamate-induced excitotoxicity of its own accord [234]. As these authors noted, this implies that ceftriaxone could have therapeutic activity in a range of neurodegenerative conditions, essentially the examples we discussed earlier as exhibiting excitotoxicity. With this mechanism in mind, ceftriaxone is nowadays under active consideration as a therapy in models of AD [235], stroke [236], TBI [237-239], and PD [240-243]. The most complete evidence consistent with this approach to date is a very recent extensive report on ceftriaxone rescuing brain function in Toxoplasma gondii-infected mice [244]. The authors documented high brain glutamate, although how this arose remains uncertain. T. gondii is a well-known TNF inducer. Being a pathogen, it possesses the PAMP activity discussed earlier.

Riluzole (6-(trifluoromethoxy)benzothiazol-2-amine), a relatively toxic material nevertheless approved for treatment of ALS, has for some time been known to be a glutamate release inhibitor and thus affecting the glutamate functions discussed above. This has been reported to include enhancing levels of glutamate re-uptake transporters [245], including in astrocytes [246, 247]. This principle is entirely consistent with findings in a mouse AD model [248] and has been extended in a recent study in which riluzole proved to reverse the same array of human gene changes in AD and aging [249]. Both research groups suggest the effects of riluzole as a possible mechanism underlying its improvement in cognitive function in their studies.

\section{Relative effectiveness of these treatments}

As discussed earlier, neurodegenerative diseases are characterized by excessive levels of extracellular cerebral glutamate that can be expected to have accumulated through its too rapid formation as well as its slowed re-uptake and conversion back to glutamine. The ideal therapy would be able to reverse both of these changes. So far as we are aware, TNF is the only endogenous mediator that, when in excess, as in the brain in these diseases, enhances cerebral glutaminase [104] and also inhibits glutamate reuptake proteins [97]. Since anti-TNF agents, both specific and non-specific, can be predicted to simultaneously reverse both of these TNF-induced changes, their efficacy in reversing this excitotoxicity can be expected, from first principles, to be higher than agent such as DON, ceftriaxone, or riluzole, which correct only one of these two pathways. 
Specific anti-TNF biologicals are expensive, but can be very effective through neutralizing a precise target, in this case excessive cerebral TNF, known to be central to the disease in question. As discussed earlier, their large size need not be a problem. In contrast, pharmaceuticals such as dithio-thalidomides, nilotinib, cannabinoids, DON, ceftriaxone, and riluzole, although less expensive, may prove to be burdened with unknown targets that generate greater side effects than anti-TNF biologicals can. They have, however, a considerable advantage in neurodegenerative disease in that when administered orally or systemically, they can traverse the BBB and get to where they are needed [143, 157, 169, 231].

\section{Conclusions}

We propose that the excess levels of TNF, and glutamate in the brain across a range of neurodegenerative diseases are crucially linked, high TNF causing extracellular glutamate to accumulate to levels high enough to inhibit synaptic activity and kill neurons by two synergistic mechanisms. As described, these are increasing glutamate production by enhancing glutaminase and simultaneously reducing glutamate clearance by inhibiting re-uptake proteins, thus causing it to accumulate in the synaptic cleft. The shared efficacy of specific anti-TNF biologicals and non-specific anti-TNF agents (thio-thalidomides, nilotinib and cannabinoids) on this superficially diverse range of conditions can thus be understood. The usefulness of DON, ceftriaxone, and riluzole, agents without apparent anti-TNF activity, but each possessing separate activities that counter one of these two influences of high TNF on glutamate accumulation, are similarly rationalized.

\section{Abbreviations}

AB: Amyloid- $\beta$; ALS: Amyotrophic lateral sclerosis; AD: Alzheimer's disease; BBB: Blood-brain barrier; CBD: Cannabidiol; CSF: Cerebrospinal fluid; DAMPs: Damage-associated molecular patterns; DON: 6-Diazo-5-oxo-norleucine; EAAT-2: Excitatory amino acid transporter 2; i.c.v.: Intracerebroventricular; i.p.: Intraperitoneally; HIV: Human immunodeficiency virus; IL-1 $\beta$ : Interleukin-1 $\beta$; PAMPs: Pathogen-associated molecular patterns; PD: Parkinson's disease; PP-2: Pyrazolopyrimidine-2; RA: Rheumatoid arthritis; T2DM: Type 2 diabetes mellitus; TBI: Traumatic brain injury; THC: Tetrahydrocannabinol; TLR: Toll-like receptor; TNF: Tumor necrosis factor

\section{Acknowledgements}

The authors are most grateful to Sharyn Wragg for the artwork in Fig. 1. The authors have no conflicts of interest that are relevant to the content of this article.

\section{Funding}

This research was supported by the National Health and Medical Research Council (NHMRC) of Australia via research project grant \#1083569, lain S. Gray in memory of Kylie, the Roth family Foundation, and the Boyarsky family. The funders had no role in the content of the text, decision to publish, or preparation of the manuscript.

\section{Authors' contributions}

IAC proposed the scope of the review. Both authors were involved in planning and editing the manuscript, blending their complementary expertise. Both authors read and approved the final manuscript.

\section{Competing interests}

The authors declare that they have no competing interests.

\section{Consent for publication}

Not applicable.

\section{Ethics approval and consent to participate}

Not applicable.

\section{Author details}

${ }^{1}$ Biomedical Sciences and Biochemistry, Research School of Biology, Australian National University, Acton, Canberra, Australian Capital Territory 0200, Australia. ${ }^{2}$ Neurodegeneration Research Group, Garvan Institute, 384 Victoria Street, Sydney, New South Wales 2010, Australia. ${ }^{3}$ SoLS, Faculty of Science, University of Technology Sydney, Sydney, NSW 2007, Australia.

Received: 23 June 2016 Accepted: 30 August 2016

Published online: 05 September 2016

\section{References}

1. Lee HG, Zhu X, Castellani RJ, Nunomura A, Perry G, Smith MA. Amyloid-beta in Alzheimer disease: the null versus the alternate hypotheses. J Pharmacol Exp Ther. 2007;321:823-9.

2. Castellani RJ, Zhu X, Lee HG, Smith MA, Perry G. Molecular pathogenesis of Alzheimer's disease: reductionist versus expansionist approaches. Int J Mol Sci. 2009;10:1386-406.

3. Mullane K, Williams M. Alzheimer's therapeutics: continued clinical failures question the validity of the amyloid hypothesis-but what lies beyond? Biochem Pharmacol. 2013;85:289-305.

4. Castello MA, Jeppson JD, Soriano S. Moving beyond anti-amyloid therapy for the prevention and treatment of Alzheimer's disease. BMC Neurol. 2014;14:169.

5. Morris GP, Clark IA, Vissel B. Inconsistencies and controversies surrounding the amyloid hypothesis of Alzheimer's disease. Acta Neuropathol Commun. 2014;2:135.

6. Aizenstein HJ, Nebes RD, Saxton JA, Price JC, Mathis CA, Tsopelas ND, Ziolko SK, James JA, Snitz BE, Houck PR, et al. Frequent amyloid deposition without significant cognitive impairment among the elderly. Arch Neurol. 2008;65:1509-17.

7. Rowe CC, Ellis KA, Rimajova M, Bourgeat P, Pike KE, Jones G, Fripp J, Tochon Danguy $H$, Morandeau L, O'Keefe $G$, et al. Amyloid imaging results from the Australian Imaging, Biomarkers and Lifestyle (AIBL) study of aging. Neurobiol Aging. 2010;31:1275-83.

8. Chou RC, Kane M, Ghimire S, Gautam S, Gui J. Treatment for rheumatoid arthritis and risk of Alzheimer's disease: a nested casecontrol analysis. CNS Drugs. 2016

9. Clark IA, Vissel B. Amyloid beta: one of three danger-associated molecules that are secondary inducers of the proinflammatory cytokines that mediate Alzheimer's disease. Br J Pharmacol. 2015;172:3714-27.

10. Itzhaki RF, Lathe R, Balin BJ, Ball MJ, Bearer EL, Braak H, Bullido MJ, Carter C, Clerici M, Cosby SL, et al. Microbes and Alzheimer's disease. J Alzheimers Dis. 2016;51:979-84.

11. Rowan MJ, Klyubin I, Wang Q, Hu NW, Anwyl R. Synaptic memory mechanisms: Alzheimer's disease amyloid beta-peptide-induced dysfunction. Biochem Soc Trans. 2007:35:1219-23.

12. Salloway S, Sperling R, Fox NC, Blennow K, Klunk W, Raskind M, Sabbagh M, Honig LS, Porsteinsson AP, Ferris S, et al. Two phase 3 trials of bapineuzumab in mild-to-moderate Alzheimer's disease. N Engl J Med. 2014;370:322-33.

13. Janus C, Pearson J, McLaurin J, Mathews PM, Jiang Y, Schmidt SD, Chishti MA, Horne P, Heslin D, French J, et al. A beta peptide immunization reduces behavioural impairment and plaques in a model of Alzheimer's disease. Nature. 2000;408:979-82.

14. Butchart J, Brook L, Hopkins V, Teeling J, Puntener U, Culliford D, Sharples R, Sharif S, McFarlane B, Raybould R, et al. Etanercept in Alzheimer disease: a randomized, placebo-controlled, double-blind, phase 2 trial. Neurology. 2015;84:2161-8 
15. Carswell EA, Old L, Kassel RL, Green S, Fiore N, Williamson B. An endotoxininduced serum factor that causes necrosis of tumors. Proc Natl Acad Sci U S A. 1975;72:3666-70.

16. Clark IA, Virelizier J-L, Carswell EA, Wood PR. Possible importance of macrophage-derived mediators in acute malaria. Infect Immun. 1981;32: 1058-66.

17. Clark IA, Alleva LE, Mills AC, Cowden WB. Pathogenesis of malaria and clinically similar conditions. Clin Microbiol Rev. 2004;17:509-39.

18. Tovey MG. The expression of cytokines in the organs of normal individuals: role in homeostasis. A review. J Biol Regul Homeost Agents. 1988;2:87-92.

19. Marano MA, Moldawer LL, Fong Y, Wei H, Minei J, Yurt R, Cerami A, Lowry SF. Cachectin/TNF production in experimental burns and Pseudomonas infection. Arch Surg. 1988;123:1383-8.

20. Nawroth PP, Bank I, Handley D, Cassimeris J, Chess L, Stern D. Tumor necrosis factor/cachectin interacts with endothelial cell receptors to induce release of interleukin 1. J Exp Med. 1986;163:1363-75

21. Elliott MJ, Maini RN, Feldmann M, Kalden JR, Antoni C, Smolen JS, Leeb B, Breedveld FC, Macfarlane JD, Bijl H, et al. Randomised double-blind comparison of chimeric monoclonal antibody to tumour necrosis factor alpha (CA2) versus placebo in rheumatoid arthritis. Lancet. 1994;344:1105-10.

22. Brennan FM, Chantry D, Jackson A, Maini R, Feldmann M. Inhibitory effect of TNF alpha antibodies on synovial cell interleukin-1 production in rheumatoid arthritis. Lancet. 1989;2:244-7.

23. Charles P, Elliott MJ, Davis D, Potter A, Kalden JR, Antoni C, Breedveld FC, Smolen JS, Eberl G, deWoody K, et al. Regulation of cytokines, cytokine inhibitors, and acute-phase proteins following anti-TNF-alpha therapy in rheumatoid arthritis. J Immunol. 1999;163:1521-8.

24. Quistad SD, Stotland A, Barott KL, Smurthwaite CA, Hilton BJ, Grasis JA, Wolkowicz R, Rohwer FL. Evolution of TNF-induced apoptosis reveals 550 My of functional conservation. Proc Natl Acad Sci U S A. 2014;111:9567-72.

25. Shoham S, Davenne D, Cady AB, Dinarello CA, Krueger JM. Recombinant tumor necrosis factor and interleukin-1 enhance slow-wave sleep. Am J Physiol. 1987;253:R142-9.

26. Sawada M, Hara N, Maeno T. Extracellular tumor necrosis factor induces a decreased $\mathrm{K}+$ conductance in an identified neuron of Aplysia kurodai. Neurosci Lett. 1990;115:219-25.

27. Sawada M, Hara N, Maeno T. Analysis of a decreased Na + conductance by tumor necrosis factor in identified neurons of Aplysia kurodai. J Neurosci Res. 1991;28:466-73.

28. Ignatowski TA, Spengler RN. Tumor necrosis factor-alpha: presynaptic sensitivity is modified after antidepressant drug administration. Brain Res. 1994;665:293-9.

29. Gadani SP, Cronk JC, Norris GT, Kipnis J. IL-4 in the brain: a cytokine to remember. J Immunol. 2012;189:4213-9.

30. Benson JM, Sachs CW, Treacy G, Zhou H, Pendley CE, Brodmerkel CM, Shankar G, Mascelli MA. Therapeutic targeting of the IL-12/23 pathways: generation and characterization of ustekinumab. Nat Biotechnol. 2011; 29:615-24.

31. Langrish CL, Chen Y, Blumenschein WM, Mattson J, Basham B, Sedgwick JD, McClanahan T, Kastelein RA, Cua DJ. IL-23 drives a pathogenic T cell population that induces autoimmune inflammation. J Exp Med. 2005;201:233-40.

32. Arvin B, Neville LF, Barone FC, Feuerstein GZ. The role of inflammation and cytokines in brain injury. Neurosci Biobehav Rev. 1996;20:445-52.

33. Barone FC, Arvin B, White RF, Miller A, Webb CL, Willette RN, Lysko PG, Feuerstein GZ. Tumor necrosis factor-alpha-a mediator of focal ischemic brain injury. Stroke. 1997;28:1233-44.

34. Tarkowski $\mathrm{E}$, Andreasen $\mathrm{N}$, Tarkowski A, Blennow K. Intrathecal inflammation precedes development of Alzheimer's disease. J Neurol Neurosurg Psychiatry. 2003;74:1200-5.

35. Esiri MM. The interplay between inflammation and neurodegeneration in CNS disease. J Neuroimmunol. 2007;184:4-16.

36. McAlpine FE, Lee JK, Harms AS, Ruhn KA, Blurton Jones M, Hong J, Das P, Golde TE, LaFerla FM, Oddo $S$, et al. Inhibition of soluble TNF signaling in a mouse model of Alzheimer's disease prevents pre-plaque amyloidassociated neuropathology. Neurobiol Dis. 2009;34:163-77.

37. Clark IA, Alleva LM, Vissel B. The roles of TNF in brain dysfunction and disease. Pharmacol Ther. 2010;128:519-48.

38. Eikelenboom $P$, Veerhuis $R$, van Exel E, Hoozemans JJ, Rozemuller AJ, van Gool WA. The early involvement of the innate immunity in the pathogenesis of late-onset Alzheimer's disease: neuropathological, epidemiological and genetic evidence. Curr Alzheimer Res. 2011;8:142-50.
39. Bhaskar K, Maphis N, Xu G, Varvel NH, Kokiko-Cochran ON, Weick JP, Staugaitis SM, Cardona A, Ransohoff RM, Herrup K, Lamb BT. Microglial derived tumor necrosis factor-alpha drives Alzheimer's disease-related neuronal cell cycle events. Neurobiol Dis. 2014;62:273-85.

40. Heneka MT, Kummer MP, Latz E. Innate immune activation in neurodegenerative disease. Nat Rev Immunol. 2014;14:463-77.

41. Lyman M, Lloyd DG, Ji X, Vizcaychipi MP, Ma D. Neuroinflammation: the role and consequences. Neurosci Res. 2014;79:1-12.

42. Marin I, Kipnis J. Learning and memory...the immune system. Learn Mem. 2013;20:601-6.

43. Harms AS, Barnum CJ, Ruhn KA, Varghese S, Trevino I, Blesch A, Tansey MG. Delayed dominant-negative TNF gene therapy halts progressive loss of nigral dopaminergic neurons in a rat model of Parkinson's disease. Mol Ther. 2011;19:46-52.

44. Ignatowski TA, Covey WC, Knight PR, Severin CM, Nickola TJ, Spengler RN. Brain-derived TNFalpha mediates neuropathic pain. Brain Res. 1999;841:70-7.

45. Covey WC, Ignatowski TA, Knight PR, Spengler RN. Brain-derived TNFalpha: involvement in neuroplastic changes implicated in the conscious perception of persistent pain. Brain Res. 2000;859:113-22.

46. Tobinick E, Davoodifar S. Efficacy of etanercept delivered by perispinal administration for chronic back and/or neck disc-related pain: a study of clinical observations in 143 patients. Curr Med Res Opin. 2004;20:1075-85.

47. Cohen SP, Bogduk N, Dragovich A, Buckenmaier 3rd CC, Griffith S, Kurihara C, Raymond J, Richter PJ, Williams N, Yaksh TL. Randomized, double-blind, placebo-controlled, dose-response, and preclinical safety study of transformational epidural etanercept for the treatment of sciatica. Anesthesiology. 2009;110:1116-26.

48. Chen YM, Chen HH, Lan JL, Chen DY. Improvement of cognition, a potential benefit of anti-TNF therapy in elderly patients with rheumatoid arthritis. Joint Bone Spine. 2010;77:366-7.

49. Hess A, Axmann R, Rech J, Finzel S, Heindl C, Kreitz S, Sergeeva M, Saake M, Garcia M, Kollias G, et al. Blockade of TNF-alpha rapidly inhibits pain responses in the central nervous system. Proc Natl Acad Sci U S A. 2011;108:3731-6.

50. Gerard E, Spengler RN, Bonoiu AC, Mahajan SD, Davidson BA, Ding H, Kumar R, Prasad PN, Knight PR, Ignatowski TA. Chronic constriction injuryinduced nociception is relieved by nanomedicine-mediated decrease of rat hippocampal tumor necrosis factor. Pain. 2015;156:1320-33.

51. Hsiao HY, Chiu FL, Chen CM, Wu YR, Chen HM, Chen YC, Kuo HC, Chern Y. Inhibition of soluble tumor necrosis factor is therapeutic in Huntington's disease. Hum Mol Genet. 2014;23:4328-44.

52. McCoy MK, Tansey MG. TNF signaling inhibition in the CNS: implications for normal brain function and neurodegenerative disease. J Neuroinflammation. 2008;5:45.

53. Belarbi K, Arellano C, Ferguson R, Jopson T, Rosi S. Chronic neuroinflammation impacts the recruitment of adult-born neurons into behaviorally relevant hippocampal networks. Brain Behav Immun. 2012;26:18-23.

54. Terrando N, Monaco C, Ma D, Foxwell BM, Feldmann M, Maze M. Tumor necrosis factor-alpha triggers a cytokine cascade yielding postoperative cognitive decline. Proc Natl Acad Sci U S A. 2010;107:20518-22.

55. Baratz R, Tweedie D, Rubovitch V, Luo W, Yoon JS, Hoffer BJ, Greig NH, Pick CG. Tumor necrosis factor-alpha synthesis inhibitor, 3,6'-dithiothalidomide, reverses behavioral impairments induced by minimal traumatic brain injury in mice. J Neurochem. 2011;118:1032-42.

56. Wilson CM, Gaber MW, Sabek OM, Zawaski JA, Merchant TE. Radiationinduced astrogliosis and blood-brain barrier damage can be abrogated using anti-TNF treatment. Int J Radiat Oncol Biol Phys. 2009;74:934-41.

57. Kesler S, Janelsins M, Koovakkattu D, Palesh O, Mustian K, Morrow G, Dhabhar FS. Reduced hippocampal volume and verbal memory performance associated with interleukin- 6 and tumor necrosis factor-alpha levels in chemotherapy-treated breast cancer survivors. Brain Behav Immun. 2013;30(Suppl):S109-16.

58. Ganz PA, Bower JE, Kwan L, Castellon SA, Silverman DH, Geist C, Breen EC, Irwin MR, Cole SW. Does tumor necrosis factor-alpha (TNF-alpha) play a role in post-chemotherapy cerebral dysfunction? Brain Behav Immun. 2013; 30(Suppl):S99-108

59. Savin C, Triesch J, Meyer-Hermann M. Epileptogenesis due to glia-mediated synaptic scaling. J R Soc Interface. 2008;4:4.

60. Yang J, He F, Meng Q, Sun Y, Wang W, Wang C. Inhibiting HIF-1alpha decreases expression of TNF-alpha and caspase-3 in specific brain regions exposed kainic acid-induced status epilepticus. Cell Physiol Biochem. 2016; 38:75-82. 
61. Kulcsar KA, Baxter VK, Abraham R, Nelson A, Griffin DE. Distinct immune responses in resistant and susceptible strains of mice during neurovirulent alphavirus encephalomyelitis. J Virol. 2015;89:8280-91.

62. John CC, Panoskaltsis Mortari A, Opoka RO, Park GS, Orchard PJ, Jurek AM, Idro R, Byarugaba J, Boivin MJ. Cerebrospinal fluid cytokine levels and cognitive impairment in cerebral malaria. Am J Trop Med Hyg. 2008;78:198-205.

63. Brabers NA, Nottet HS. Role of the pro-inflammatory cytokines TNF-alpha and IL-1 beta in HIV-associated dementia. Eur J Clin Invest. 2006:36:447-58

64. Wood LB, Winslow AR, Proctor EA, McGuone D, Mordes DA, Frosch MP, Hyman BT, Lauffenburger DA, Haigis KM. Identification of neurotoxic cytokines by profiling Alzheimer's disease tissues and neuron culture viability screening. Sci Rep. 2015;5:16622.

65. McEntee WJ, Crook TH. Glutamate: its role in learning, memory, and the aging brain. Psychopharmacology (Berl). 1993;111:391-401.

66. Thomas RJ. Excitatory amino acids in health and disease. J Am Geriatr Soc 1995:43:1279-89.

67. Zhou Y, Danbolt NC. Glutamate as a neurotransmitter in the healthy brain. Neural Transm (Vienna). 2014;121:799-817.

68. Bezzi P, Domercq M, Brambilla L, Galli R, Schols D, De Clerca E, Vescovi A, Bagetta G, Kollias G, Meldolesi J, Volterra A. CXCR4-activated astrocyte glutamate release via TNFalpha: amplification by microglia triggers neurotoxicity. Nat Neurosci. 2001;4:702-10.

69. Albensi BC, Mattson MP. Evidence for the involvement of TNF and NFkappaB in hippocampal synaptic plasticity. Synapse. 2000;35:151-9.

70. Bonansco C, Couve A, Perea G, Ferradas CA, Roncagliolo M, Fuenzalida M. Glutamate released spontaneously from astrocytes sets the threshold for synaptic plasticity. Eur J Neurosci. 2011;33:1483-92.

71. Choi DW. Glutamate neurotoxicity and diseases of the nervous system. Neuron. 1988;1:623-34

72. Miulli DE, Norwell DY, Schwartz FN. Plasma concentrations of glutamate and its metabolites in patients with Alzheimer's disease. J Am Osteopath Assoc. 1993:93:670-6.

73. Loschmann PA, Lange KW, Wachtel H, Turski L. MPTP-induced degeneration: interference with glutamatergic toxicity. J Neural Transm Suppl. 1994;43:133-43.

74. Behrens PF, Franz P, Woodman B, Lindenberg KS, Landwehrmeyer GB Impaired glutamate transport and glutamate-glutamine cycling: downstream effects of the Huntington mutation. Brain. 2002;125:1908-22.

75. Spreux-Varoquaux O, Bensimon G, Lacomblez L, Salachas F, Pradat PF, Le Forestier N, Marouan A, Dib M, Meininger V. Glutamate levels in cerebrospinal fluid in amyotrophic lateral sclerosis: a reappraisal using a new HPLC method with coulometric detection in a large cohort of patients. J Neurol Sci. 2002;193:73-8.

76. Benveniste $\mathrm{H}$, Drejer J, Schousboe A, Diemer NH. Elevation of the extracellular concentrations of glutamate and aspartate in rat hippocampus during transient cerebral ischemia monitored by intracerebral microdialysis. J Neurochem. 1984:43:1369-74.

77. Nargi-Aizenman JL, Griffin DE. Sindbis virus-induced neuronal death is both necrotic and apoptotic and is ameliorated by N-methyl-D-aspartate receptor antagonists. J Virol. 2001;75:7114-21.

78. Darman J, Backovic S, Dike S, Maragakis NJ, Krishnan C, Rothstein JD, Irani DN Kerr DA. Viral-induced spinal motor neuron death is non-cell-autonomous and involves glutamate excitotoxicity. J Neurosci. 2004;24:7566-75.

79. Toklu HZ, Uysal MK, Kabasakal L, Sirvanci S, Ercan F, Kaya M. The effects of riluzole on neurological, brain biochemical, and histological changes in early and late term of sepsis in rats. J Surg Res. 2009;152:238-48.

80. Li Y, Wang S, Ran K, Hu Z, Liu Z, Duan K. Differential hippocampal protein expression between normal aged rats and aged rats with postoperative cognitive dysfunction: a proteomic analysis. Mol Med Rep. 2015;12:2953-60.

81. Alaoui F, Pratt J, Trocherie S, Court L, Stutzmann JM. Acute effects of irradiation on the rat brain: protection by glutamate blockade. Eur J Pharmacol. 1995:276:55-60.

82. Fundytus ME. Glutamate receptors and nociception: implications for the drug treatment of pain. CNS Drugs. 2001;15:29-58.

83. Valdes M, Collado A, Bargallo N, Vazquez M, Rami L, Gomez E, Salamero M. Increased glutamate/glutamine compounds in the brains of patients with fibromyalgia: a magnetic resonance spectroscopy study. Arthritis Rheum. 2010;62:1829-36.

84. Spranger M, Schwab S, Krempien S, Winterholler M, Steiner T, Hacke W. Excess glutamate levels in the cerebrospinal fluid predict clinical outcome of bacterial meningitis. Arch Neurol. 1996;53:992-6.
85. Meldrum BS. The role of glutamate in epilepsy and other CNS disorders. Neurology. 1994;44:S14-23.

86. Ferrarese C, Aliprandi A, Tremolizzo L, Stanzani L, De Micheli A, Dolara A, Frattola L. Increased glutamate in CSF and plasma of patients with HIV dementia. Neurology. 2001;57:671-5.

87. Miranda AS, Vieira LB, Lacerda-Queiroz N, Souza AH, Rodrigues DH, Vilela MC, Gomez MV, Machado FS, Rachid MA, Teixeira AL. Increased levels of glutamate in the central nervous system are associated with behavioral symptoms in experimental malaria. Braz J Med Biol Res. 2010;43:1173-7.

88. Stover JF, Schoning B, Beyer TF, Woiciechowsky C, Unterberg AW. Temporal profile of cerebrospinal fluid glutamate, interleukin-6, and tumor necrosis factor-alpha in relation to brain edema and contusion following controlled cortical impact injury in rats. Neurosci Lett. 2000;288:25-8.

89. Ruppel RA, Kochanek PM, Adelson PD, Rose ME, Wisniewski SR, Bell MJ, Clark RS, Marion DW, Graham SH. Excitatory amino acid concentrations in ventricular cerebrospinal fluid after severe traumatic brain injury in infants and children: the role of child abuse. J Pediatr. 2001:138:18-25.

90. Fontana AC, Fox DP, Zoubroulis A, Mortensen OV, Raghupathi R. Neuroprotective effects of the glutamate transporter activator (R)-(-)-5methyl-1-nicotinoyl-2-pyrazoline (MS-153) following traumatic brain injury in the adult rat. J Neurotrauma. 2015, in press.

91. Jourdain P, Bergersen LH, Bhaukaurally K, Bezzi P, Santello M, Domercq M, Matute C, Tonello F, Gundersen V, Volterra A. Glutamate exocytosis from astrocytes controls synaptic strength. Nat Neurosci. 2007;10:331-9.

92. Lewerenz J, Maher P. Chronic glutamate toxicity in neurodegenerative diseases_-what is the evidence? Front Neurosci. 2015;9:469.

93. Kiaei M, Petri S, Kipiani K, Gardian G, Choi DK, Chen J, Calingasan NY, Schafer P, Muller GW, Stewart C, et al. Thalidomide and lenalidomide extend survival in a transgenic mouse model of amyotrophic lateral sclerosis. J Neurosci. 2006:26:2467-73.

94. Hsiao HY, Chen YC, Chen HM, Tu PH, Chern Y. A critical role of astrocytemediated nuclear factor-kappaB-dependent inflammation in Huntington's disease. Hum Mol Genet. 2013;22:1826-42.

95. Haroon E, Fleischer CC, Felger JC, Chen X, Woolwine BJ, Patel T, Hu XP, Miller AH. Conceptual convergence: increased inflammation is associated with increased basal ganglia glutamate in patients with major depression. Mol Psychiatry. 2016, in press.

96. Danbolt NC. Glutamate uptake. Prog Neurobiol. 2001;65:1-105.

97. Fine SM, Angel RA, Perry SW, Epstein LG, Rothstein JD, Dewhurst S, Gelbard HA. Tumor necrosis factor alpha inhibits glutamate uptake by primary human astrocytes_-implications for pathogenesis of HIV-1 dementia. J Biol Chem. 1996;271:15303-6.

98. Zou JY, Crews FT. TNF alpha potentiates glutamate neurotoxicity by inhibiting glutamate uptake in organotypic brain slice cultures: neuroprotection by NF kappa B inhibition. Brain Res. 2005;1034:11-24.

99. Carmen J, Rothstein JD, Kerr DA. Tumor necrosis factor-alpha modulates glutamate transport in the CNS and is a critical determinant of outcome from viral encephalomyelitis. Brain Res. 2009;1263:143-54.

100. Stellwagen D, Beattie EC, Seo JY, Malenka RC. Differential regulation of AMPA receptor and GABA receptor trafficking by tumor necrosis factoralpha. J Neurosci. 2005:25:3219-28.

101. Dumont AO, Goursaud S, Desmet N, Hermans E. Differential regulation of glutamate transporter subtypes by pro-inflammatory cytokine TNF-alpha in cortical astrocytes from a rat model of amyotrophic lateral sclerosis. PLoS One. 2014;9:e97649.

102. Olmos G, Llado J. Tumor necrosis factor alpha: a link between neuroinflammation and excitotoxicity. Mediators Inflamm. 2014;2014:861231.

103. Viviani B, Boraso M, Marchetti N, Marinovich M. Perspectives on neuroinflammation and excitotoxicity: a neurotoxic conspiracy? Neurotoxicology. 2014;43:10-20.

104. Takeuchi H, Jin S, Wang J, Zhang G, Kawanokuchi J, Kuno R, Sonobe Y, Mizuno T, Suzumura A. Tumor necrosis factor-alpha induces neurotoxicity via glutamate release from hemichannels of activated microglia in an autocrine manner. J Biol Chem. 2006:281:21362-8.

105. Chen CJ, Ou YC, Chang CY, Pan HC, Liao SL, Chen SY, Raung SL, Lai CY. Glutamate released by Japanese encephalitis virus-infected microglia involves TNF-alpha signaling and contributes to neuronal death. Glia. 2012;60:487-501.

106. Ye L, Huang Y, Zhao L, Li Y, Sun L, Zhou Y, Qian G, Zheng JC. IL-1 beta and TNF-alpha induce neurotoxicity through glutamate production: a potential role for neuronal glutaminase. J Neurochem. 2013;125:897-908.

107. Ye J, Jiang R, Cui M, Zhu B, Sun L, Wang Y, Zohaib A, Dong Q, Ruan X, Song $Y$, et al. Etanercept reduces neuroinflammation and lethality in mouse model of Japanese encephalitis. J Infect Dis. 2014;210:875-89. 
108. Osborn LM, Kamphuis W, Wadman WJ, Hol EM. Astrogliosis: an integral player in the pathogenesis of Alzheimer's disease. Prog Neurobiol. 2016

109. Moulder KL, Meeks JP, Mennerick S. Homeostatic regulation of glutamate release in response to depolarization. Mol Neurobiol. 2006;33:133-53.

110. Malarkey EB, Ni Y, Parpura V. Ca2+ entry through TRPC1 channels contributes to intracellular $\mathrm{Ca} 2+$ dynamics and consequent glutamate release from rat astrocytes. Glia. 2008;56:821-35.

111. Santos MS, Li H, Voglmaier SM. Synaptic vesicle protein trafficking at the glutamate synapse. Neuroscience. 2009;158:189-203.

112. Weitzel LR, Wischmeyer PE. Glutamine in critical illness: the time has come, the time is now. Crit Care Clin. 2010;26:515-25. ix-x.

113. Heyland DK, Elke G, Cook D, Berger MM, Wischmeyer PE, Albert M, Muscedere J, Jones G, Day AG. Glutamine and antioxidants in the critically ill patient: a post hoc analysis of a large-scale randomized trial. JPEN J Parenter Enteral Nutr. 2015:39:401-9.

114. Morales I, Rodriguez M. Self-induced accumulation of glutamate in striatal astrocytes and basal ganglia excitotoxicity. Glia. 2012;60:1481-94.

115. Castillo J, Loza MI, Mirelman D, Brea J, Blanco M, Sobrino T, Campos F. A novel mechanism of neuroprotection: blood glutamate grabber. J Cereb Blood Flow Metab. 2015;36:292-301.

116. Jing $H$, Hao Y, Bi Q, Zhang J, Yang P. Intra-amygdala microinjection of TNFalpha impairs the auditory fear conditioning of rats via glutamate toxicity. Neurosci Res. 2015:91:34-40.

117. Chio CC, Lin JW, Chang MW, Wang CC, Yang CZ, Chang CP. Therapeutic evaluation of etanercept in a model of traumatic brain injury. J Neurochem. 2010;115:921-9.

118. Kang YM, He RL, Yang LM, Qin DN, Guggilam A, Elks C, Yan N, Guo Z, Francis J. Brain tumour necrosis factor-alpha modulates neurotransmitters in hypothalamic paraventricular nucleus in heart failure. Cardiovasc Res. 2009; 83:737-46.

119. Kang YM, Wang Y, Yang LM, Elks C, Cardinale J, Yu XJ, Zhao XF, Zhang J, Zhang LH, Yang ZM, Francis J. TNF-alpha in hypothalamic paraventricular nucleus contributes to sympathoexcitation in heart failure by modulating AT1 receptor and neurotransmitters. Tohoku J Exp Med. 2010;222:251-63.

120. Jabaudon D, Shimamoto K, Yasuda-Kamatani Y, Scanziani M, Gahwiler BH, Gerber U. Inhibition of uptake unmasks rapid extracellular turnover of glutamate of nonvesicular origin. Proc Natl Acad Sci U S A. 1999;96:8733-8.

121. Tobinick EL, Britschgi-Davoodifar S. Perispinal TNF-alpha inhibition for discogenic pain. Swiss Med Wkly. 2003;133:170-7.

122. Tobinick EL, Gross H. Rapid cognitive improvement in Alzheimer's disease following perispinal etanercept administration. J Neuroinflammation. 2008;5:2.

123. Griffin WS. Perispinal etanercept: potential as an Alzheimer therapeutic. J Neuroinflammation. 2008:5:3

124. Tobinick E. Rapid improvement of chronic stroke deficits after perispinal etanercept: three consecutive cases. CNS Drugs. 2011;25:145-55.

125. Tobinick E, Kim NM, Reyzin G, Rodriguez-Romanacce H, DePuy V. Selective TNF inhibition for chronic stroke and traumatic brain injury: an observational study involving 629 consecutive patients treated with perispinal etanercept. CNS Drugs. 2012;26:1051-70.

126. Ignatowski TA, Spengler RN, Dhandapani KM, Folkersma H, Butterworth RF, Tobinick E. Perispinal etanercept for post-stroke neurological and cognitive dysfunction: Scientific rationale and current evidence. CNS Drugs. 2014;28:679-97.

127. Tobinick $E$, Rodriguez-Romanacce $H$, Levine A, lgnatowski TA, Spengler RN. Immediate neurological recovery following perispinal etanercept years after brain injury. Clin Drug Investig. 2014;34:361-6.

128. Tobinick E. Deciphering the physiology underlying the rapid clinical effects of perispinal etanercept in Alzheimer's disease. Current Alzheimers Dis. 2012; 9:99-109.

129. Peppel K, Crawford D, Beutler B. A tumor necrosis factor (TNF) receptor-lgG heavy chain chimeric protein as a bivalent antagonist of TNF activity. J Exp Med. 1991;174:1483-9.

130. Emery P, Vencovsky J, Sylwestrzak A, Leszczynski P, Porawska W, Baranauskaite A, Tseluyko V, Zhdan VM, Stasiuk B, Milasiene R, et al. A phase III randomised, double-blind, parallel-group study comparing SB4 with etanercept reference product in patients with active rheumatoid arthritis despite methotrexate therapy. Ann Rheum Dis. 2015, in press.

131. Lee YJ, Shin D, Kim Y, Kang JW, Gauliard A, Fuhr R. A randomised phase I pharmacokinetic study comparing SB4 and etanercept reference product (Enbrel(R)) in healthy subjects. Br J Clin Pharmacol. 2016;82: 64-73.

132. Azevedo VF, Galli N, Kleinfelder A, D'Ippolito J, Urbano PC. Etanercept biosimilars. Rheumatol Int. 2015;35:197-209.
133. Chapman K, Adjei A, Baldrick P, da Silva A, De Smet K, DiCicco R, Hong SS Jones D, Leach MW, McBlane J, et al. Waiving in vivo studies for monoclonal antibody biosimilar development: national and global challenges. MAbs. 2016:8:427-35.

134. Probert $L$. TNF and its receptors in the CNS: The essential, the desirable and the deleterious effects. Neuroscience. 2015;302:2-22.

135. Baune BT. Inflammation and neurodegenerative disorders: is there still hope for therapeutic intervention? Curr Opin Psychiatry. 2015;28:148-54.

136. Baeten D, van Hagen PM. Use of TNF blockers and other targeted therapies in rare refractory immune-mediated inflammatory diseases: evidence-based or rational? Ann Rheum Dis. 2010;69:2067-73.

137. Tobinick EL. Perispinal delivery of CNS drugs. CNS Drugs. 2016;30:469-80.

138. Wen TS, Randall DC, Zolman JF. Protein accumulation in cerebrospinal fluid during -90 degrees head-down tilt in rabbit. J Appl Physiol. 1994;77:1081-6.

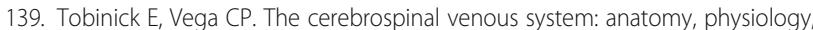
and clinical implications. Med Gen Med. 2006;8:53.

140. Tobinick EL. Perispinal etanercept for neuroinflammatory disorders. Drug Discov Today. 2009;14:168-77.

141. Tobinick EL, Gross H, Weinberger A, Cohen H. TNF-alpha modulation for treatment of Alzheimer's disease: a 6-month pilot study. Medscape Gen Med Neurol Neurosurg. 2006:8:25.

142. Yoon JS, Lee JH, Tweedie D, Mughal MR, Chigurupati S, Greig NH, Mattson MP. 3,6'-dithiothalidomide improves experimental stroke outcome by suppressing neuroinflammation. J Neurosci Res. 2013;91:671-80.

143. Cabral GA, Jamerson M. Marijuana use and brain immune mechanisms. Int Rev Neurobiol. 2014;118:199-230

144. Chio CC, Chang CH, Wang CC, Cheong CU, Chao CM, Cheng BC, Yang CZ, Chang CP. Etanercept attenuates traumatic brain injury in rats by reducing early microglial expression of tumor necrosis factor-alpha. BMC Neurosci. 2013;14:33.

145. Pardridge WM. Drug transport across the blood-brain barrier. J Cereb Blood Flow Metab. 2012:32:1959-72.

146. Armagen: http://www.prnewswire.com/news-releases/armagentechnologies-inc-announces-17-million-series-a-financing-181460481.html. 2012

147. Pardridge WM. Blood-brain barrier drug delivery of IgG fusion proteins with a transferrin receptor monoclonal antibody. Expert Opin Drug Deliv. 2015; 12:207-22.

148. Couch JA, Yu YJ, Zhang Y, Tarrant JM, Fuji RN, Meilandt WJ, Solanoy H, Tong RK, Hoyte K, Luk W, et al. Addressing safety liabilities of TfR bispecific antibodies that cross the blood-brain barrier. Sci Transl Med. 2013;5: 183ra157. 181-112

149. Bien-Ly N, Yu YJ, Bumbaca D, Elstrott J, Boswell CA, Zhang Y, Luk W, Lu Y, Dennis MS, Weimer RM, et al. Transferrin receptor (TfR) trafficking determines brain uptake of TfR antibody affinity variants. J Exp Med. 2014 211:233-44

150. Yu YJ, Atwal JK, Zhang Y, Tong RK, Wildsmith KR, Tan C, Bien-Ly N, Hersom M, Maloney JA, Meilandt WJ, et al. Therapeutic bispecific antibodies cross the blood-brain barrier in nonhuman primates. Sci Transl Med. 2014;6: 261 ra154

151. Zhou QH, Boado RJ, Hui EK, Lu JZ, Pardridge WM. Brain-penetrating tumor necrosis factor decoy receptor in the mouse. Drug Metab Dispos. 2011:39:71-6.

152. Sumbria RK, Boado RJ, Pardridge WM. Brain protection from stroke with intravenous TNFalpha decoy receptor-Trojan horse fusion protein. J Cereb Blood Flow Metab. 2012;32:1933-8.

153. Shi NQ, Qi XR, Xiang B, Zhang Y. A survey on "Trojan Horse" peptides: opportunities, issues and controlled entry to "Troy". J Control Release. 2014; 194:53-70.

154. Sampaio EP, Sarno EN, Galilly R, Cohn ZA, Kaplan G. Thalidomide selectively inhibits tumor necrosis factor-alpha production by stimulated human monocytes. J Exp Med. 1991;173:699-703.

155. Moreira AL, Sampaio EP, Zmuidzinas A, Frindt P, Smith KA, Kaplan G. Thalidomide exerts its inhibitory action on tumor necrosis factor alpha by enhancing mRNA degradation. J Exp Med. 1993;177:1675-16780.

156. Zhu X, Giordano T, Yu QS, Holloway HW, Perry TA, Lahiri DK, Brossi A, Greig $\mathrm{NH}$. Thiothalidomides: novel isosteric analogues of thalidomide with enhanced TNF-alpha inhibitory activity. J Med Chem. 2003:46:5222-9.

157. Greig NH, Giordano T, Zhu X, Yu QS, Perry TA, Holloway HW, Brossi A, Rogers JT, Sambamurti K, Lahiri DK. Thalidomide-based TNF-alpha inhibitors for neurodegenerative diseases. Acta Neurobiol Exp. 2004;64:1-9. 
158. Belarbi K, Jopson T, Tweedie D, Arellano C, Luo W, Greig NH, Rosi S TNF-alpha protein synthesis inhibitor restores neuronal function and reverses cognitive deficits induced by chronic neuroinflammation. J Neuroinflamm. 2012;9:23.

159. Tweedie D, Ferguson RA, Fishman K, Frankola KA, Van Praag $H$, Holloway HW, Luo W, Li Y, Caracciolo L, Russo I, et al. Tumor necrosis factor-alpha synthesis inhibitor 3,6'-dithiothalidomide attenuates markers of inflammation. Alzheimer pathology and behavioral deficits in animal models of neuroinflammation and Alzheimer's disease. J Neuroinflammation. 2012;9:106.

160. Gabbita SP, Srivastava MK, Eslami P, Johnson MF, Kobritz NK, Tweedie D, Greig NH, Zemlan FP, Sharma SP, Harris-White ME. Early intervention with a small molecule inhibitor for tumor necrosis factor-alpha prevents cognitive deficits in a triple transgenic mouse model of Alzheimer's disease. J Neuroinflammation. 2012;9:99.

161. Russo I, Caracciolo L, Tweedie D, Choi SH, Greig NH, Barlati S, Bosetti F. 3,6'Dithiothalidomide, a new TNF-alpha synthesis inhibitor, attenuates the effect of Abeta1-42 intracerebroventricular injection on hippocampal neurogenesis and memory deficit. J Neurochem. 2012;122:1181-92.

162. Song T, Ma X, Gu K, Yang Y, Yang L, Ma P, Wang W, Zhao J, Yan R, Guan J, et al. Thalidomide represses inflammatory response and reduces radiculopathic pain by inhibiting IRAK-1 and NF-kappaB/p38/JNK signaling. J Neuroimmunol. 2016;290:1-8.

163. Boycott HE, Wilkinson JA, Boyle JP, Pearson HA, Peers C. Differential involvement of TNF alpha in hypoxic suppression of astrocyte glutamate transporters. Glia. 2008;56:998-1004.

164. Maekawa T, Ashihara E, Kimura S. The Bcr-Abl tyrosine kinase inhibitor imatinib and promising new agents against Philadelphia chromosomepositive leukemias. Int J Clin Oncol. 2007;12:327-40.

165. Breccia M, Alimena G. Nilotinib: a second-generation tyrosine kinase inhibitor for chronic myeloid leukemia. Leuk Res. 2010;34:129-34.

166. Pagan F. Society for Neuroscience (SfN) 2015 Annual Meeting. Abstract 12. 01. Presented October 18, 2015. 2015.

167. Hebron ML, Lonskaya I, Moussa CE. Nilotinib reverses loss of dopamine neurons and improves motor behavior via autophagic degradation of alphasynuclein in Parkinson's disease models. Hum Mol Genet. 2013;22:3315-28.

168. Tanabe A, Yamamura Y, Kasahara J, Morigaki R, Kaji R, Goto S. A novel tyrosine kinase inhibitor AMN107 (nilotinib) normalizes striatal motor behaviors in a mouse model of Parkinson's disease. Front Cell Neurosci. 2014;8:50.

169. Karuppagounder SS, Brahmachari S, Lee Y, Dawson VL, Dawson TM, Ko HS. The c-Abl inhibitor, nilotinib, protects dopaminergic neurons in a preclinical animal model of Parkinson's disease. Sci Rep. 2014:4:4874.

170. Dhawan G, Combs CK. Inhibition of Src kinase activity attenuates amyloid associated microgliosis in a murine model of Alzheimer's disease. J Neuroinflammation. 2012;9:117

171. Dhawan G, Floden AM, Combs CK. Amyloid-beta oligomers stimulate microglia through a tyrosine kinase dependent mechanism. Neurobiol Aging. 2012;33:2247-61.

172. Lonskaya I, Hebron ML, Desforges NM, Schachter JB, Moussa CE. Nilotinib-induced autophagic changes increase endogenous parkin level and ubiquitination, leading to amyloid clearance. J Mol Med (Berl). 2014:92:373-86.

173. Ocuin LM, Zeng S, Cavnar MJ, Sorenson EC, Bamboat ZM, Greer JB, Kim TS, Popow R, DeMatteo RP. Nilotinib protects the murine liver from ischemia/ reperfusion injury. J Hepatol. 2012;57:766-73.

174. El-Agamy DS. Nilotinib ameliorates lipopolysaccharide-induced acute lung injury in rats. Toxicol Appl Pharmacol. 2011;253:153-60.

175. McCoy MK, Martinez TN, Ruhn KA, Szymkowski DE, Smith CG, Botterman BR, Tansey KE, Tansey MG. Blocking soluble tumor necrosis factor signaling with dominant-negative tumor necrosis factor inhibitor attenuates loss of dopaminergic neurons in models of Parkinson's disease. J Neurosci. 2006;26:9365-75.

176. Blake SJ, Lyons AB, Hughes TP. Nilotinib inhibits the Src-family kinase LCK and T-cell function in vitro. J Cell Mol Med. 2009;13:599-601.

177. Ferlito M, Romanenko OG, Guyton K, Ashton S, Squadrito F, Halushka PV, Cook JA. Implication of Galpha i proteins and Src tyrosine kinases in endotoxin-induced signal transduction events and mediator production. J Endotoxin Res. 2002;8:427-35.

178. Chawla A, Nguyen KD, Goh YP. Macrophage-mediated inflammation in metabolic disease. Nat Rev Immunol. 2011;11:738-49.
179. Mokhtari $D$, Welsh N. Potential utility of small tyrosine kinase inhibitors in the treatment of diabetes. Clin Sci (Lond). 2010;118:241-7.

180. Chattopadhyay S, Sen GC. Tyrosine phosphorylation in Toll-like receptor signaling. Cytokine Growth Factor Rev. 2014;25:533-41.

181. Xiong Y, Murphy M, Manavalan TT, Pattabiraman G, Qiu F, Chang HH, Ho IC, Medvedev AE. Endotoxin tolerance inhibits lyn and c-Src phosphorylation and association with toll-like receptor 4 but increases expression and activity of protein phosphatases. J Innate Immun. 2015

182. Mechoulam R, Hanus L. A historical overview of chemical research on cannabinoids. Chem Phys Lipids. 2000;108:1-13.

183. de Vries M, van Rijckevorsel DC, Wilder-Smith OH, van Goor H. Dronabinol and chronic pain: importance of mechanistic considerations. Expert Opin Pharmacother. 2014;15:1525-34.

184. Piomelli D. The molecular logic of endocannabinoid signalling. Nat Rev Neurosci. 2003:4:873-84.

185. Xu JY, Chen C. Endocannabinoids in synaptic plasticity and neuroprotection Neuroscientist. 2015:21:152-68.

186. Kinsey SG, Long JZ, O'Neal ST, Abdullah RA, Poklis JL, Boger DL, Cravatt BF, Lichtman AH. Blockade of endocannabinoid-degrading enzymes attenuates neuropathic pain. J Pharmacol Exp Ther. 2009;330:902-10.

187. Johnson JR, Burnell-Nugent M, Lossignol D, Ganae-Motan ED, Potts R, Fallon MT. Multicenter, double-blind, randomized, placebo-controlled, parallelgroup study of the efficacy, safety, and tolerability of THC:CBD extract and THC extract in patients with intractable cancer-related pain. J Pain Symptom Manage. 2010;39:167-79.

188. Guindon J, Guijarro A, Piomelli D, Hohmann AG. Peripheral antinociceptive effects of inhibitors of monoacylglycerol lipase in a rat model of inflammatory pain. Br J Pharmacol. 2011;163:1464-78.

189. Lau BK, Vaughan CW. Targeting the endogenous cannabinoid system to treat neuropathic pain (some toxicity, anti-TNF at least specific). Front Pharmacol. 2014;5:28.

190. Serpell M, Ratcliffe S, Hovorka J, Schofield M, Taylor L, Lauder H, Ehler E. A doubleblind, randomized, placebo-controlled, parallel group study of THC/CBD spray in peripheral neuropathic pain treatment. Eur J Pain. 2014;18:999-1012.

191. Chen X, Zhang J, Chen C. Endocannabinoid 2-arachidonoylglycerol protects neurons against beta-amyloid insults. Neuroscience. 2011:178:159-68.

192. Cheng D, Low JK, Logge W, Garner B, Karl T. Chronic cannabidiol treatment improves social and object recognition in double transgenic APPswe/PS1E9 mice. Psychopharmacology (Berl). 2014;231:3009-17.

193. Cheng D, Spiro AS, Jenner AM, Garner B, Karl T. Long-term cannabidiol treatment prevents the development of social recognition memory deficits in Alzheimer's disease transgenic mice. J Alzheimers Dis. 2014;42:1383-96.

194. Karl T, Cheng D, Garner B, Arnold JC. The therapeutic potential of the endocannabinoid system for Alzheimer's disease. Expert Opin Ther Targets. 2012;16:407-20

195. Ramirez BG, Blazquez C, Gomez del Pulgar T, Guzman M, de Ceballos ML. Prevention of Alzheimer's disease pathology by cannabinoids: neuroprotection mediated by blockade of microglial activation. J Neurosci. 2005;25:1904-13.

196. Wallace MJ, Blair RE, Falenski KW, Martin BR, DeLorenzo RJ. The endogenous cannabinoid system regulates seizure frequency and duration in a model of temporal lobe epilepsy. J Pharmacol Exp Ther. 2003;307:129-37.

197. Blair RE, Deshpande LS, Sombati S, Falenski KW, Martin BR, DeLorenzo RJ. Activation of the cannabinoid type-1 receptor mediates the anticonvulsant properties of cannabinoids in the hippocampal neuronal culture models of acquired epilepsy and status epilepticus. J Pharmacol Exp Ther. 2006;317:1072-8.

198. Bhaskaran MD, Smith BN. Cannabinoid-mediated inhibition of recurrent excitatory circuitry in the dentate gyrus in a mouse model of temporal lobe epilepsy. PLoS One. 2010;5:e10683.

199. Soltesz I, Alger BE, Kano M, Lee SH, Lovinger DM, Ohno-Shosaku T, Watanabe M. Weeding out bad waves: towards selective cannabinoid circuit control in epilepsy. Nat Rev Neurosci. 2015;16:264-77.

200. Price DA, Martinez AA, Seillier A, Koek W, Acosta Y, Fernandez E, Strong R, Lutz B, Marsicano G, Roberts JL, Giuffrida A. WIN55,212-2, a cannabinoid receptor agonist, protects against nigrostriatal cell loss in the 1-methyl-4phenyl-1,2,3,6-tetrahydropyridine mouse model of Parkinson's disease. Eur J Neurosci. 2009;29:2177-86

201. Chung YC, Bok E, Huh SH, Park JY, Yoon SH, Kim SR, Kim YS, Maeng S, Park $\mathrm{SH}$, Jin BK. Cannabinoid receptor type 1 protects nigrostriatal dopaminergic neurons against MPTP neurotoxicity by inhibiting microglial activation. J Immunol. 2011;187:6508-17. 
202. Fernandez-Suarez D, Celorrio M, Riezu-Boj Jl, Ugarte A, Pacheco R, Gonzalez H, Oyarzabal J, Hillard CJ, Franco R, Aymerich MS. Monoacylglycerol lipase inhibitor JZL184 is neuroprotective and alters glial cell phenotype in the chronic MPTP mouse model. Neurobiol Aging. 2014;35:2603-16.

203. Lu TS, Avraham HK, Seng S, Tachado SD, Koziel H, Makriyannis A, Avraham S. Cannabinoids inhibit HIV-1 Gp120-mediated insults in brain microvascular endothelial cells. J Immunol. 2008;181:6406-16.

204. Bari M, Rapino C, Mozetic P, Maccarrone M. The endocannabinoid system in gp120-mediated insults and HIV-associated dementia. Exp Neurol. 2010;224:74-84.

205. Kim HJ, Shin AH, Thayer SA. Activation of cannabinoid type 2 receptors inhibits HIV-1 envelope glycoprotein gp120-induced synapse loss. Mol Pharmacol. 2011;80:357-66.

206. Solbrig MV, Fan Y, Hazelton P. Prospects for cannabinoid therapies in viral encephalitis. Brain Res. 2013;1537:273-82.

207. Panikashvili D, Simeonidou C, Ben-Shabat S, Hanus L, Breuer A, Mechoulam $R$, Shohami E. An endogenous cannabinoid (2-AG) is neuroprotective after brain injury. Nature. 2001;413:527-31.

208. Fernandez-Lopez D, Pazos MR, Tolon RM, Moro MA, Romero J, Lizasoain I, Martinez-Orgado J. The cannabinoid agonist WIN55212 reduces brain damage in an in vivo model of hypoxic-ischemic encephalopathy in newborn rats. Pediatr Res. 2007;62:255-60.

209. Carloni S, Alonso-Alconada D, Girelli S, Duranti A, Tontini A, Piomelli D, Hilario E, Alvarez A, Balduini W. Pretreatment with the monoacylglycerol lipase inhibitor URB602 protects from the long-term consequences of neonatal hypoxic-ischemic brain injury in rats. Pediatr Res. 2012;72:400-6.

210. Pazos MR, Mohammed N, Lafuente H, Santos M, Martinez-Pinilla E, Moreno E, Valdizan E, Romero J, Pazos A, Franco R, et al. Mechanisms of cannabidiol neuroprotection in hypoxic-ischemic newborn pigs: role of $5 \mathrm{HT}(1 \mathrm{~A})$ and CB2 receptors. Neuropharmacology. 2013;71:282-91.

211. Gallily R, Breuer A, Mechoulam R. 2-Arachidonylglycerol, an endogenous cannabinoid, inhibits tumor necrosis factor-alpha production in murine macrophages, and in mice (endogenous). Eur J Pharmacol. 2000;406:R5-7.

212. Facchinetti F, Del Giudice E, Furegato S, Passarotto M, Leon A. Cannabinoids ablate release of TNFalpha in rat microglial cells stimulated with lypopolysaccharide (both synthetic and endogenous). Glia. 2003;41:161-8.

213. Haj CG, Sumariwalla PF, Hanus L, Kogan NM, Yektin Z, Mechoulam R, Feldmann M, Gallily R. HU-444, a novel, potent anti-inflammatory, nonpsychotropic cannabinoid (puts TNF down). J Pharmacol Exp Ther. 2015; 355:66-75.

214. Campos AC, Brant F, Miranda AS, Machado FS, Teixeira AL. Cannabidiol increases survival and promotes rescue of cognitive function in a murine model of cerebral malaria. Neuroscience. 2015;289:166-80.

215. Gordon EB, Hart GT, Tran TM, Waisberg M, Akkaya M, Kim AS, Hamilton SE, Pena M, Yazew T, Qi CF, et al. Targeting glutamine metabolism rescues mice from late-stage cerebral malaria. Proc Natl Acad Sci U S A. 2015;112:13075-80.

216. Shen M, Piser TM, Seybold VS, Thayer SA. Cannabinoid receptor agonists inhibit glutamatergic synaptic transmission in rat hippocampal cultures. J Neurosci. 1996;16:4322-34.

217. Hajos N, Ledent C, Freund TF. Novel cannabinoid-sensitive receptor mediates inhibition of glutamatergic synaptic transmission in the hippocampus. Neuroscience. 2001;106:1-4.

218. Gerdeman G, Lovinger DM. CB1 cannabinoid receptor inhibits synaptic release of glutamate in rat dorsolateral striatum. J Neurophysiol. 2001;85:468-71.

219. Domenici MR, Azad SC, Marsicano G, Schierloh A, Wotjak CT, Dodt HU, Zieglgansberger W, Lutz B, Rammes G. Cannabinoid receptor type 1 located on presynaptic terminals of principal neurons in the forebrain controls glutamatergic synaptic transmission. J Neurosci. 2006;26:5794-9.

220. Takahashi KA, Castillo PE. The CB1 cannabinoid receptor mediates glutamatergic synaptic suppression in the hippocampus. Neuroscience. 2006;139:795-802

221. Barzegar S, Komaki A, Shahidi S, Sarihi A, Mirazi N, Salehi I. Effects of cannabinoid and glutamate receptor antagonists and their interactions on learning and memory in male rats. Pharmacol Biochem Behav. 2015;131:87-90.

222. Coffey GL, Ehrlich J, Fisher MW, Hillegas AB, Kohberger DL, Machamer HE, Rightsel WA, Roegner FR. 6-Diazo-5-oxo-L-norleucine, a new tumorinhibitory substance. I. Biologic studies. Antibiot Chemother (Northfield). 1956:6:487-97.

223. Conti F, Minelli A. Glutamate immunoreactivity in rat cerebral cortex is reversibly abolished by 6-diazo-5-oxo-L-norleucine (DON), an inhibitor of phosphate-activated glutaminase. J Histochem Cytochem. 1994;42:717-26.
224. Earhart RH, Koeller JM, Davis HL. Phase I trial of 6-diazo-5-oxo-L-norleucine (DON) administered by 5-day courses. Cancer Treat Rep. 1982;66:1215-7.

225. Takeuchi H, Jin S, Suzuki H, Doi Y, Liang J, Kawanokuchi J, Mizuno T, Sawada $M$, Suzumura A. Blockade of microglial glutamate release protects against ischemic brain injury. Exp Neurol. 2008;214:144-6.

226. Prow NA, Irani DN. The inflammatory cytokine, interleukin-1 beta, mediates loss of astroglial glutamate transport and drives excitotoxic motor neuron injury in the spinal cord during acute viral encephalomyelitis. J Neurochem. 2008;105:1276-86.

227. Potter MC, Baxter VK, Mathey RW, Alt J, Rojas C, Griffin DE, Slusher BS. Neurological sequelae induced by alphavirus infection of the CNS are attenuated by treatment with the glutamine antagonist 6-diazo-5-oxo-Inorleucine. J Neurovirol. 2015;21:159-73.

228. Zhao J, Lopez AL, Erichsen D, Herek S, Cotter RL, Curthoys NP, Zheng J. Mitochondrial glutaminase enhances extracellular glutamate production in HIV-1-infected macrophages: linkage to HIV-1 associated dementia. J Neurochem. 2004;88:169-80.

229. Shijie J, Takeuchi H, Yawata I, Harada Y, Sonobe Y, Doi Y, Liang J, Hua L, Yasuoka S, Zhou Y, et al. Blockade of glutamate release from microglia attenuates experimental autoimmune encephalomyelitis in mice. Tohoku J Exp Med. 2009;217:87-92.

230. Van Hensbroek MB, Palmer A, Onyiorah E, Schneider G, Jaffar S, Dolan G, Memming $H$, Frenkel J, Enwere $G$, Bennett $S$, et al. The effect of a monoclonal antibody to tumor necrosis factor on survival from childhood cerebral malaria. J Infect Dis. 1996;174:1091-7.

231. Vogel KR, Arning E, Wasek BL, Bottiglieri T, Gibson KM. Non-physiological amino acid (NPAA) therapy targeting brain phenylalanine reduction: pilot studies in PAHENU2 mice. J Inherit Metab Dis. 2013;36:513-23.

232. Meloni F, Ballabio P, Bianchi L, Grassi FA, Gialdroni Grassi GG. Cefodizime modulates in vitro tumor necrosis factor-alpha, interleukin-6 and interleukin-8 release from human peripheral monocytes. Chemotherapy. 1995;41:289-95.

233. Rawls SM, Tallarida R, Robinson W, Amin M. The beta-lactam antibiotic, ceftriaxone, attenuates morphine-evoked hyperthermia in rats. $\mathrm{Br} J$ Pharmacol. 2007;151:1095-102.

234. Lee SG, Su ZZ, Emdad L, Gupta P, Sarkar D, Borjabad A, Volsky DJ, Fisher PB. Mechanism of ceftriaxone induction of excitatory amino acid transporter-2 expression and glutamate uptake in primary human astrocytes. J Biol Chem. 2008;283:13116-23.

235. Zumkehr J, Rodriguez-Ortiz CJ, Cheng D, Kieu Z, Wai T, Hawkins C, Kilian J, Lim SL, Medeiros R, Kitazawa M. Ceftriaxone ameliorates tau pathology and cognitive decline via restoration of glial glutamate transporter in a mouse model of Alzheimer's disease. Neurobiol Aging. 2015;36:2260-71.

236. Inui T, Alessandri B, Heimann A, Nishimura F, Frauenknecht K, Sommer C, Kempski O. Neuroprotective effect of ceftriaxone on the penumbra in a rat venous ischemia model. Neuroscience. 2013;242:1-10.

237. Wei J, Pan X, Pei Z, Wang W, Qiu W, Shi Z, Xiao G. The beta-lactam antibiotic, ceftriaxone, provides neuroprotective potential via antiexcitotoxicity and anti-inflammation response in a rat model of traumatic brain injury. J Trauma Acute Care Surg. 2012;73:654-60.

238. Goodrich GS, Kabakov AY, Hameed MQ, Dhamne SC, Rosenberg PA, Rotenberg A. Ceftriaxone treatment after traumatic brain injury restores expression of the glutamate transporter, GLT-1, reduces regional gliosis, and reduces post-traumatic seizures in the rat. J Neurotrauma. 2013;30:1434-41.

239. Cui C, Cui Y, Gao J, Sun L, Wang Y, Wang K, Li R, Tian Y, Song S, Cui J. Neuroprotective effect of ceftriaxone in a rat model of traumatic brain injury. Neurol Sci. 2014;35:695-700

240. Leung TC, Lui CN, Chen LW, Yung WH, Chan YS, Yung KK. Ceftriaxone ameliorates motor deficits and protects dopaminergic neurons in 6hydroxydopamine-lesioned rats. ACS Chem Neurosci. 2012;3:22-30.

241. Chotibut T, Davis RW, Arnold JC, Frenchek Z, Gurwara S, Bondada V, Geddes JW, Salvatore MF. Ceftriaxone increases glutamate uptake and reduces striatal tyrosine hydroxylase loss in 6-OHDA Parkinson's model. Mol Neurobiol. 2014:49:1282-92.

242. Huang CK, Chang YT, Amstislavskaya TG, Tikhonova MA, Lin CL, Hung CS, Lai TJ, Ho YJ. Synergistic effects of ceftriaxone and erythropoietin on neuronal and behavioral deficits in an MPTP-induced animal model of Parkinson's disease dementia. Behav Brain Res. 2015;294:198-207.

243. Weng JN, Tikhonova MA, Chen JH, Shen MS, Meng WY, Chang YT, Chen KH, Liang KC, Hung CS, Amstislavskaya TG, Ho YJ. Ceftriaxone prevents the neurodegeneration and decreased neurogenesis seen in a Parkinson's disease rat model: an immunohistochemical and MRI study. Behav Brain Res. 2016:305:126-39. 
244. David CN, Frias ES, Szu JI, Vieira PA, Hubbard JA, Lovelace J, Michael M, Worth D, McGovern KE, Ethell IM, et al. GLT-1-dependent disruption of CNS glutamate homeostasis and neuronal function by the protozoan parasite Toxoplasma gondii. PLoS Pathog. 2016;12:e1005643.

245. Fumagalli E, Funicello M, Rauen T, Gobbi M, Mennini T. Riluzole enhances the activity of glutamate transporters GLAST, GLT1 and EAAC1. Eur J Pharmacol. 2008;578:171-6.

246. Carbone M, Duty S, Rattray M. Riluzole elevates GLT-1 activity and levels in striatal astrocytes. Neurochem Int. 2012;60:31-8.

247. Dall'Igna OP, Bobermin LD, Souza DO, Quincozes-Santos A. Riluzole increases glutamate uptake by cultured C6 astroglial cells. Int J Dev Neurosci. 2013;31:482-6.

248. Hunsberger HC, Weitzner DS, Rudy CC, Hickman JE, Libell EM, Speer RR, Gerhardt GA, Reed MN. Riluzole rescues glutamate alterations, cognitive deficits, and tau pathology associated with P301L tau expression. J Neurochem. 2015;135:381-94.

249. Pereira AC, Gray JD, Kogan JF, Davidson RL, Rubin TG, Okamoto M, Morrison $J H$, McEwen BS. Age and Alzheimer's disease gene expression profiles reversed by the glutamate modulator riluzole. Mol Psychiatry. 2016

Submit your next manuscript to BioMed Central and we will help you at every step:

- We accept pre-submission inquiries

- Our selector tool helps you to find the most relevant journal

- We provide round the clock customer support

- Convenient online submission

- Thorough peer review

- Inclusion in PubMed and all major indexing services

- Maximum visibility for your research

Submit your manuscript at www.biomedcentral.com/submit
Biomed Central 